\title{
Biological Activity of Berberine-A Summary Update
}

\author{
Anna Och ${ }^{1, *(1)}$, Rafał Podgórski ${ }^{2}$ and Renata Nowak ${ }^{1}$ \\ 1 Chair and Department of Pharmaceutical Botany, Medical University of Lublin, 1 Chodźki St., 20-093 Lublin, \\ Poland; renatanowak@umlub.pl \\ 2 Department of Biochemistry, Institute of Medical Sciences, Medical College of Rzeszów University, \\ 16c Rejtana St., 35-959 Rzeszów, Poland; rpodgorski@ur.edu.pl \\ * Correspondence: anna.ochagn@wp.pl; Tel.: +48-(50)-4050167
}

Received: 2 November 2020; Accepted: 10 November 2020; Published: 12 November 2020

\begin{abstract}
Berberine is a plant metabolite belonging to the group of isoquinoline alkaloids with strong biological and pharmacological activity. Currently, berberine is receiving considerable interest due to its anticancer activity based on many biochemical pathways, especially its proapoptotic and anti-inflammatory activity. Therefore, the growing number of papers on berberine demands summarizing the knowledge and research trends. The efficacy of berberine in breast and colon cancers seems to be the most promising aspect. Many papers focus on novel therapeutic strategies based on new formulations or search for new active derivatives. The activity of berberine is very important as regards sensitization and support of anticancer therapy in combination with well-known but in some cases inefficient therapeutics. Currently, the compound is being assessed in many important clinical trials and is one of the most promising and intensively examined natural agents.
\end{abstract}

Keywords: berberine; anticancer; metabolic syndrome; apoptosis; clinical trials; bioavailability

Key Contribution: Berberine is a plant metabolite receiving considerable interest due to its potent pharmacological activity. This compound is currently being comprehensively examined and its anticancer activity reflected in the proapoptotic effect seems to be the most promising trend of research.

\section{Introduction}

Alkaloids with strong activity have always been used in traditional medicine as plant extracts. Currently, with the new research methods, active compounds in extracts can be established and designed for new applications. One of them is berberine, which is currently receiving great interest due to its extremely promising biological and pharmacological activity (Figure 1). The earliest information on the medical use of Rhizoma coptidis containing berberine is dated in A.D. 200. [1]. Recent berberine research has not only confirmed the significance of its use in traditional Chinese medicine, where it was applied in various diseases, for example infections and gastrointestinal disorders [2], but has also proved its anticancer activity and effectiveness in neurological and metabolic disorders. Despite its poor bioavailability, limiting its application [3], berberine is currently being assessed in many important clinical trials, which encourages deeper examination of the mechanisms of its action and a search for new applications. The most promising is the anticancer use of berberine. Berberine not only possesses documented proapoptotic activity, which is in the focus of attention, but also seems to be a very important and promising compound in combined cancer treatment. Sensitization and elimination of drug resistance are very promising trends in the berberine research. What is more, berberine exhibits low toxicity towards healthy cells, which makes it safe for clinical use and proves its activity in biochemical disorders. Due to the low bioavailability and poor pharmacokinetic parameters, research of new forms of berberine administration and its new active derivatives has begun. The latest 
papers from 2019 and 2020 seem to focus on this priority and attempt to solve the problem to provide efficient berberine-based therapy.

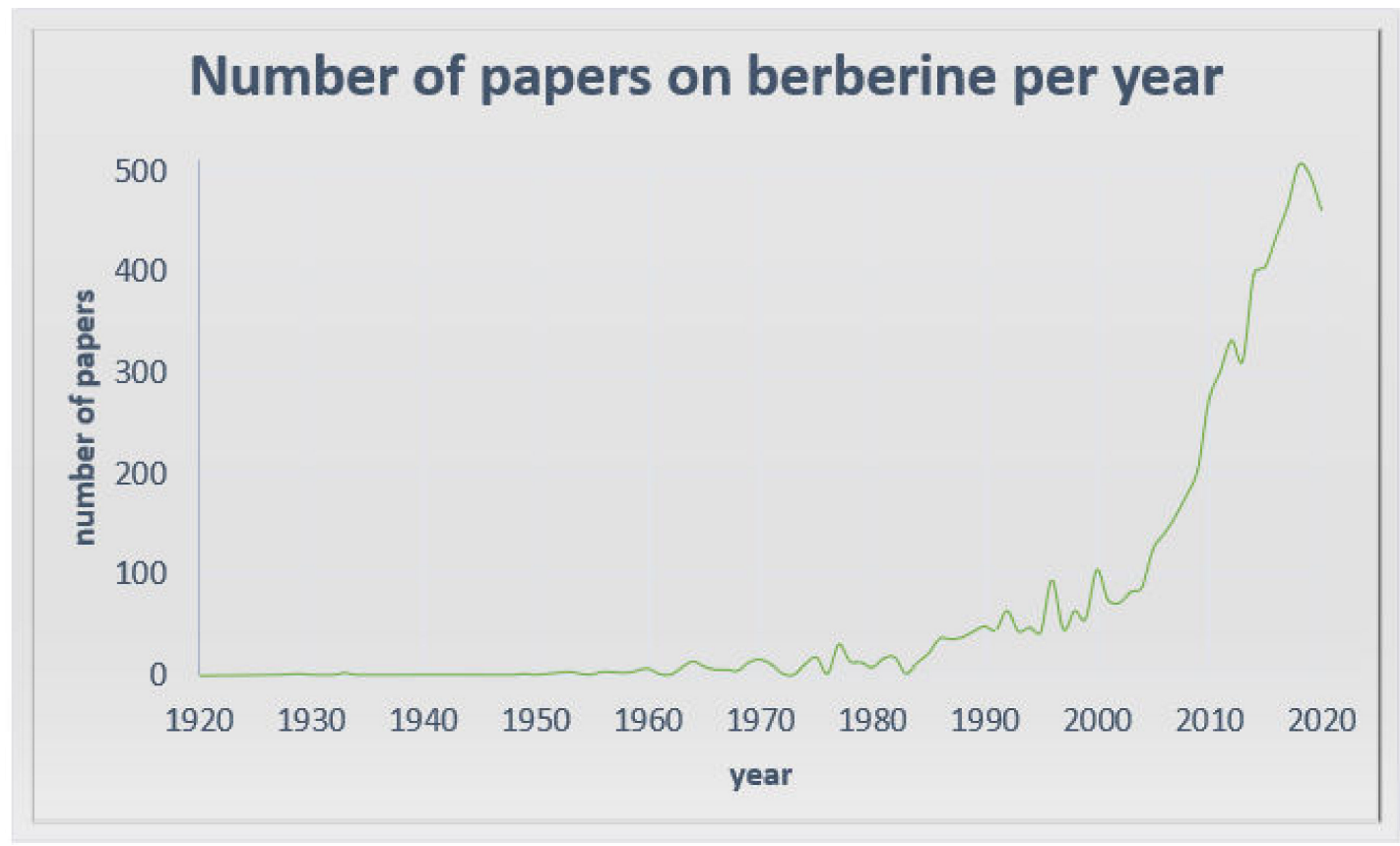

Figure 1. Structure of the number of publications on berberine based on the PubMed database: https://pubmed.ncbi.nlm.nih.gov.

\section{Berberine in Cardiovascular and Metabolic Diseases}

\subsection{Cholesterol-Lowering Effect}

Berberine has been clinically examined quite extensively as regards its beneficial influence on the cardiovascular system. Berberine has an antiarrhythmic effect, improves ejection fraction and enhances the function of the left ventricle and general physical capacity in congestive heart failure [4]. Berberine decreases blood pressure by reducing cholesterol via several mechanisms, e.g., it stimulates the capture of cholesterol in serum by liver, stimulates the disposal of LDL-C from blood [2,5], reduces the absorption of cholesterol in bowels, enhances cholesterol excretion in excrements and stimulates liver exchange of cholesterol and the formation of bile acid [6]. It also stimulates AMPK (protein kinase activated by $5^{\prime}$ adenosine monophosphate), which may limit fatty acid synthesis [7]. Reduced TC, TG and LDL-C concentration and an increased HDL-C concentration were noted after three months of application of the compound [8]. In HepG2 cells, i.e., a human hepatoma cell line in primary hepatocytes, berberine inhibited the synthesis of cholesterol and triglyceride. It also lowers cholesterol levels in vivo [2].

\subsection{Antidiabetic Action}

In type 2 diabetes mellitus, berberine was first reported in 1986 [9]. Indirect clinical investigations of the effect of berberine proved that it reduced alanine and aspartate transaminase levels in diabetic patients [9]. It was reported as a successful agent alleviating insulin resistance [10]. The hypoglycemic effect of berberine is comparable to metformin. Berberine, likewise to metformin, regulates a variety of effectors, such as AMPK and MAPK (mitogen activated protein kinase) [11]. Hyperinsulinemia and insulin resistance, typical for type 2 diabetes are crucial in polycystic ovary syndrome pathogenesis [12]. Hence, berberine is considered effective in polycystic ovary syndrome, but this issue needs further investigation [13]. It has been clinically confirmed that berberine enhances ovulation in polycystic ovary syndrome by reducing insulin resistance [14]. Moreover, the effect of berberine on the lipid 
profile in women with polycystic ovary syndrome is highly beneficial. The intake of $500 \mathrm{mg}$ berberine for 3 months significantly improved the profile in treated patients. A higher pregnancy rate and a lower incidence of severe ovarian hyperstimulation syndrome were noticed as well [15]. In addition, the treatment with berberine instead of metformin entailed fewer adverse effects and reduced lipid parameters and BMI (Body Mass Index) [10].

\subsection{Antiobesity Action}

As mentioned previously, berberine is a potential drug for treatment of obesity. It acts by downregulation of adipogenesis and lipogenesis. This antiobesity activity is connected with the fact that berberine strongly decreased the size and number of droplets of lipid in the 3T3-L1 adipocyte cell line. The mitigation of high glucose-induced podocyte apoptosis after berberine treatment described currently is equally promising for diabetic patients. In this case, the alkaloid modulates autophagy and it proceeds via the mTOR/P70S6K/4EBP1 pathway [11]. A long-term body weight loss effect is observed after expousure to berberine. The effect is exerted through enhancing ATGL expression (AMPK-mediated) and increases the basal lipolysis state of triglycerides in adipocytes.

Crucial for the transcription factor of adipogenesis is PPAR $\gamma$. Berberine inhibits adipocyte differentiation via PPAR $\gamma$ and $\mathrm{C} / \mathrm{EBP} \alpha$ pathways. Besides, berberine inhibits the proliferation and differentiation of preadipocytes [9]. With its regulatory function in insulin resistance and dyslipidemia, berberine can be a potential agent in metabolic syndrome. However, the overall effect of berberine in metabolic syndrome has not been systemically tested, partly because the preclinical models for metabolic syndrome are limited [16].

The anticancer activity of berberine via an effect on kinases, described in the further part of the article, is possibly also related to its effects on kinase-mediated lipid metabolic pathways. Insulin resistance development in obesity involves JNK kinases [17] and neurotransmitter excitotoxicity in ischemic conditions. [18]. Hong et al. described that berberine reduced the phosphorylation of JNK in gastric cancer cells [19], but the influence of berberine on kinases is strongly dependent on many conditions [20-22].

\section{Berberine in Neurodegenerative and Neuropsychiatric Disorders}

The ability to ameliorate hyperlipidemia and hyperglycemia make berberine supportive in neurologic disease $[23,24]$. Recent studies have shown that berberine exerts a protective effect on the central nervous system, which makes it a promising agent in disorders such as Alzheimer's disease, cerebral ischemia, mental depression, anxiety and schizophrenia $[25,26]$. Berberine exerts a neuroprotective effect by regulating early immune activation of peripheral lymphocytes and immunotolerance in vivo [27]. However, this is not fully understood and there are reports on berberine exacerbating neurodegeneration [28].

Berberine also significantly decreases the production of kynurenine, which when increased, is metabolized to neurotoxic compounds (for example quinolinic acid), and influences glutamatergic neurotransmission [3,29]. It has been described that berberine inhibits the effects of reward after abuse of drugs such as cocaine, morphine and ethanol. It proceeds through downregulation of tyrosine hydroxylase expression or other mechanisms [23,30,31]. Researchers suggest that alkaloids may rapidly act like antidepressants; hence, it is indicated as a potential substance for the treatment of patients with major depression. Berberine, like other antidepressant drugs, affects sigma receptor 1. Studies also show that berberine can act as an antidepressant via the NF- $\mathrm{KB}$ (nuclear factor kappa-light-chain-enhancer of activated B cells) signaling pathway, which is activated by oxidative stress. This berberine antidepressant effect also results from its impact on the brain-derived neurotrophic factor-cAMP-response element-binding protein pathway. This well-known antidepressant pathway is crucial for the antidepressant action of drugs. Berberine acts by elevation of neurotrophic factor levels and restores the decreased level of its mRNA $[3,29]$. Berberine easily crosses the blood-brain barrier after systemic administration, which enhances its potential in treatment of neurological diseases [23,24]. 


\section{Anticancer Activity of Berberine}

The first study of the cytotoxic activity of berberine was published in 1986 [32]. Later studies demonstrated the cytotoxic activity of berberine towards many cancer cell lines such as the promyelocytic leukemia HL-60 cell line [33,34], uterine cancer HeLa cell line [35,36], lymphocytic leukemia L1210 cell line, myelomonocytic leukemia WEHI-3 cell line [37], myeloid leukemia K562 cell line [38], large intestine cancer HT29 cell line [39,40], bladder cancer BIU-87 and T24 cell lines [41], hepatoma HepG2 cell line, non-small cell lung cancer [20,42], Lewis lung cancer [43], astrocytoma G95/VGH and GBM 8401 cell lines [44], melanoma B16 cell line and model U937 cell line [45]. Berberine is cytotoxic towards cancer cell lines and this activity is dependent on the dose and time. Studies have shown many mechanisms of the anticancer activity of berberine. In the assessment of the levels of expression of a panel of 44 genes in the human colon adenocarcinoma HCA-7 cell line, berberine treatment resulted in downregulation of 33 genes differently involved in the cell cycle, differentiation and epithelial-mesenchymal transition in a time- and dose-dependent manner [46]. The therapeutic window of berberine in most cases is narrow and depends on the dosage and type of cells that are treated.

\subsection{Cell Cycle Arrest}

It has been shown that berberine in low concentrations arrests human cancer cells in the G1 phase, while high concentrations arrest the cell cycle in the G2/M phase $[29,47]$.

Berberine has been shown to inhibit the cell cycle in the G1 phase by upregulation of the BTG2 gene (B cell translocation gene 2), which is a cell proliferation regulatory gene induced by the p53 protein. The arrest of the cell cycle in the G2/M phase is p53 independent [47-49].

The arrest of the cell cycle in the G0/G1 phase after exposure to berberine was reported in lymphocytic leukemia cell line L1210 [35] and bladder cancer cells BIU-87 and T24 cell lines [50]. Colon cancer cells exposed to berberine were characterized by G0/G1 phase cell cycle arrest with downregulation of the antiapoptotic gene BCL2 in a concentration-dependent manner [51-53].

Cyclins seem to be an important target for cell cycle arrest induced by berberine. Downregulation of cyclin D1 was observed after exposure to berberine in the G1 cell cycle phase [47]. Reduction of the expression of cyclin B1 by berberine and the increase in the expression of Wee1 can arrest tumor cells in the G1 and G2 phases [47,54]. G0/G1 arrest was observed in MDA-MB-231 and MCF-7 breast cancer cells after exposure to berberine, possibly due to a decrease in the level of the cell cycle regulatory protein cyclin B1. This effect was also dose dependent [47].

As reported by Chidambara et al., arrest of the cell cycle in the G2/M phase by berberine is dependent on the REV3 gene. Cells of the DT40 line deficient in REV3 are hypersensitive to berberine and their DNA undergoes double-strand breaks much more strongly than the DNA of wild-type cells after exposure to berberine [55]. Berberine-induced inhibition of the cell cycle in the G2/M phase has also been described in colorectal cancer cells of the SW480 line [56].

\subsection{Apoptosis Induction}

One of the most important and comprehensively examined processes triggered by exposure to berberine, as regards its anticancer activity, is apoptosis. Induction of a number of biochemical events i.e., a decrease in the mitochondrial membrane potential, release of cytochrome c, Bcl2 family proteins and caspase activation or PARP breakdown after exposure to berberine, confirms the proapoptotic abilities of berberine [57].

Berberine induces apoptosis in tumor cells, mainly via upregulation of proapoptotic genes and downregulation of antiapoptotic genes $[34,58]$. Changes in the gene expression in leukemic cells exposed to berberine showed that, despite low cytotoxicity of observed dosage, the compound significantly increased the expression of caspase genes CASP3, CASP8 and CASP9 and proapoptotic genes BAK1, BAX and BIK. Simultaneously, downregulation of the expression of antiapoptotic genes 
BCL2, BCL2L2, BNIP1 and BNIP3 was noticed. This indicates that gene regulation leads to the apoptosis caused by berberine [34].

In other studies, after exposure of cells from the HL-60 [33], U937 and B16 lines [45] to berberine, activation of protein caspase -3 and -9 , an increase in Bax (Bcl2-associated X protein) and a decrease in the Bcl-2 protein level were reported [33]. Additionally, an increase in the level of important proapoptotic proteins taking part in apoptosis signaling pathways such as $\mathrm{p} 53, \mathrm{Rb}$ (retinoblastoma Protein), ATM (serine/threonine kinase), caspase-8, Fas Receptor (death receptor)/FasL (Fas ligand), BID (BH3 interacting-domain death agonist, a proapoptotic member of the Bcl-2 protein family) and TNF (tumor necrosis factor) was reported. On the other hand, a decrease in the level of c-IAP1 (inhibitor of apoptosis protein), XIAP (X-linked Inhibitor of apoptosis protein), Bcl-X and Survivin (antiapoptotic protein) was reported after exposure to berberine. Among other mechanisms, berberine was shown to regulate proapoptotic and antiapoptotic proteins through an increase in the level of ROS-an important agent in apoptosis regulation [22,58,59].

An important role in berberine-induced apoptosis is played by death receptors, known as TRAIL receptor 2. TRAIL (tumor necrosis factor related apoptosis inducing ligand) is an apoptosis-inducing ligand associated with the tumor necrosis factor. It is known that TRIAL has great potential in the treatment of cancer, as it induces apoptosis by binding to the aforementioned receptors that induce tumor cell death, i.e., the so-called "death receptors"—DR4 and DR5. TRAIL induces apoptosis selectively; however, the development of partial or complete resistance limits its use. Berberine shows synergy with TRAIL. Moreover, it sensitizes cancer cells with TRAIL resistance. In TRAIL-sensitive (MDA-MB-231) and -resistant (MDA-MB-468) human breast cancer cell lines, berberine synergized with TRAIL, but it also sensitized the resistant cells to TRAIL. The markers of the process were caspase- 3 and PARP 9 Poly (ADP-ribose) polymerase 1 cleavage and p53. The berberine sensitization to TRAIL-induced apoptosis is not limited to TRAIL-resistant MDA-MB-468 breast cancer cells. Despite the moderate cytotoxic effect on breast cancer cell line 4T1 in vitro, berberine in combination with antiDR5 markedly inhibited primary growth of tumor and reduced tumor metastasis to the lungs $[54,60]$.

\subsection{Influence on $M A P K$}

There are many scientific reports on the effects of berberine on mitogen-activated kinases (called MAP or MAPK), which are involved in directing cellular responses to a variety of stimuli. They regulate processes that are very important in carcinogenesis, e.g., gene expression, mitosis, apoptosis, proliferation and differentiation [29].

Berberine has been shown to modulate mitogen-activated protein kinase signaling pathways, such as extracellular signal regulated kinase 1/2 (ERK1/2), p38 MAPK (p38 mitogen-activated protein kinases) and c-Jun N-terminal kinase (JNK) pathways. Compounds modulating these pathways are noteworthy as potential anticancer drugs. The effect depends on the type of cell. Berberine activates MAPK in human colon cancer cells [61], non-small cell lung cancer cells and human hepatoma cells (HepG2) [20,21]. In turn, in human HeLa cervical carcinoma cells, berberine enhances phosphorylation of JNK and ERK1/2 but inhibits phosphorylation of p38 MAPK [62]. In a Hong et al.'s study, berberine reduced the p38 MAPK, ERK1/2 and JNK phosphorylation in gastric cancer cells [19]. The JNK/p38 MAPK signaling pathway is disrupted in many types of cancer [63]. It was found that berberine suppressed the invasion and migration of cancer cells through blocking the JNK/p38 signaling pathway in the gastric cancer SNU-1 cell line [22].

One of the more precisely described phenomena in this field of berberine activity is its influence on MAPK via the impact of micro RNA inhibiting the translation of certain proteins, the dysfunction of which plays a role in formation of, e.g., non-small cells lung cancer. Abnormal levels of these proteins are correlated with the tissue factor TF, which contributes to tumor metastasis of non-small cells lung cancer. It has been shown to activate signaling cascades, including MAPK. In human lung cancer A549 cells, apoptosis through the miR-19a/TF/MAPK signaling pathway has been described after exposure 
to berberine [21]. Berberine raises the level of miR-19a and lowers the level of TF, thus activating MAPK signaling leading to apoptosis of cancer cells [21].

The cyclin-dependent kinase inhibitor p21 (CIP1/WAF1) is involved in the cell cycle control, cell differentiation, apoptosis and DNA replication [27]. It is linked with p53 and FOXO3a in the control of cancer cell growth [64-66]. FOXO3a (human protein Forkhead box O3) is a transcription factor from a family of transcription factors with tumor suppressor activity. It is regulated by growth factor receptor-induced activation of the phosphatidylinositol 3-kinase (PI3-K)/Akt signaling pathway. Its activation is connected with apoptosis [67] and cell cycle arrest [68] and, in various types of cells, it is associated with tumor suppression. Inhibition of FOXO3a causes tumor progression [69]. Zheng et al. demonstrated that, in non-small cell lung cancer, berberine inhibited proliferation and induced apoptosis by activating the p38 $\alpha$ MAPK signaling pathway, resulting in an increase in p53 and FOXO3a and induction of the cell cycle inhibitor p21 (CIP1/WAF1) [20].

\subsection{Trancription Regulation}

Berberine also exhibits activity against the very important transcription factor-1 (AP-1), which is closely related to neoplastic transformation. AP- 1 consists of complexes comprising the following families of DNA-binding proteins: Fos family (c-Fos, Fra-1, FosB and Fra-2,), Jun family (c-Jun, JunD, JunB and v-Jun), ATF/cyclic AMP-responsive element-binding (b-ATF, ATF1-4, ATF-6 and ATFx) and Maf family (c-Maf, MafA, MafB, MafG/F/K and $\mathrm{Nrl}$ ), which play a key role in inflammation, proliferation and apoptosis. The activity of AP-1 is regulated by, e.g., growth factors, infections, cytokines, UV radiation, or cellular stress [70].

Extrinsic carcinogens can induce increased AP1 activity [71]. Many human tumors overexpress members of the Jun protein family [72-74]. Overexpression of these proteins has been described in aggressive forms of lymphomas [75,76] and in breast cancer [74]. However, increased expression of c-Fos is observed in endometrial cancer and osteosarcoma, while decreased expression of c-Fos is associated with the progression of ovarian and gastric cancer [77]. The role of the Fos family in tumor development is thus tissue-specific [70]. Studies have shown that in general AP-1 activation depends on the type of extrinsic stimulus and the cellular condition may have different effects on the cell fate. It has been shown that the AP-1 protein was inhibited in hepatoma cells of the HepG2 line after exposure to berberine [39,78]. In turn, in oral administration of berberine, spontaneous metastasis of Lewis lung cancer cells from mediastinal lymph nodes to lung parenchyma was inhibited through AP-1 protein activation [43]. After oral administration of berberine, decreased expression of the C-fos proto-oncogene was described [54]. Thus, the influence of berberine on the AP1-protein family depends on the cell type and requires further investigations.

\subsection{Inhibition of Metastasis}

Berberine is a potential agent to halt or prevent metastasis. It acts at several points of cancer progression. One is its strong influence on matrix metalloproteinases-important proteins involved in degradation of the barrier of extracellular matrix - the first and important step in tumor cell metastasis.

Changed expression and levels of MMP activity are strongly involved in the development of many cancers. Increased MMP-2 activity is associated with poor prognosis in such types of cancer as colon, breast, melanoma, ovary, prostate and lung cancers [79]. Changes in MMP-2 activity may also be derived from changes in the levels of activation, inhibition and secretion or transcription of the MMP group of enzymes. MMP production in many cancers is elevated in the surrounding stromal tissue, but not in the tumor, and cases of metastasis are correlated with higher levels of MMP-2 mRNA in surrounding healthy tissue [80]. MMP-2 and MMP-9 can degrade type IV collagen, i.e., a major component of the basement membrane that is important for maintaining tissue organization and provides cell signaling and polarity. The degradation of the extracellular matrix allows cells to migrate from the tumor to form metastases. This is an essential step in the metastatic progression in most cancers [80]. Moreover, products of degradation of MMPs further promote MMP activity [81]. Berberine 
inhibits the expression of matrix metalloproteinase-2 (MMP-2) and matrix metalloproteinase-9 (MMP-9) in a time- and concentration-dependent manner. In tests on mice, berberine was found to reduce metalloproteinase levels in plasma [82].

The regulation of the expression of matrix metalloproteinases by berberine proceeds through the inhibition of the transfer of p-STAT3 (signal transducer and activator of transcription 3) to the nucleus. In colon cancer cells it significantly reduces the level of JAK2 (Janus kinase 2-A protein from the Janus kinase family) and STAT3 phosphorylation. Phosphorylated molecules p-JAK2 and p-STAT3 are significantly increased in colorectal cancer cells overexpressing COX2 (cyclooxygenase-2). Overexpression of COX2 induces the activation of JAK-STAT, which increases the levels of metalloproteinases-MMP-2 and MMP-9 in colon cancer cells. Berberine markedly decreased the levels of phosphorylated JAK2 and phosphorylated STAT3 in colorectal cancer cells and effectively interrupted the COX2/JAK/STAT signaling pathway [23,29], which was observed as a decrease in the level of metalloproteinases $[54,83]$.

Berberine reduces protein levels of the STAT3 in nasopharyngeal carcinoma cells and blocks STAT3 activation induced by IL-6 secreted by tumor-associated fibroblasts. Similar to the Janus kinase family, the family of kinases of the transcription factors of the STAT plays an important role in the immunity process, cell division, cell death and tumor formation [84].

\subsection{Inhibition of Angiogenesis}

Another mechanism of berberine in the antiprogression process is inhibition of angiogenesis.

Additionally, in this case, the influence on metalloproteinases 2 and 9 plays a crucial role. MMP-2 plays an important role in the formation of new blood vessels in tumors by supporting the migration of endothelial cells. It is crucial in the angiogenesis process, which is essential for tumor progression. An increased level of expression and higher activity of MMP-2 is observed with increased vascularization of the metastases of lung cancer in the central nervous system [85]. It has been shown that MMP-2 may affect tumor viability and invasiveness also by regulating lymphangiogenesis [80]. In contrast, MMP-9 and other metalloproteinases play a role in angiogenesis by promoting mobilization of VEGF (vascular endothelial growth factor) [80]. Berberine inhibits metastases by impeding angiogenesis through the effects on MMP-2 and MMP-9. However, inhibition of angiogenesis by berberine does not only affect metalloproteinases.

In B16F-10 melanoma cells exposed to berberine, decreased expression of genes encoding angiogenesis-promoting factors, i.e., COX-2, HIF (hypoxia induced factor) and VEGF were reported [58]. Additionally, in the liver cancer HepG2 cell line and the gastric adenocarcinoma SC-M1 cell line, berberine was found to inhibit cell proliferation, migration, vascular endothelium formation and VEGF expression [86]. In breast cancer cells, berberine reduced the expression of VEGF and fibronectin by inhibiting the PI-3K/AKT pathway [84]. Inhibition of NF- $\mathrm{KB}$ in tumor cells is also one of the mechanisms of a berberine-induced decrease in the expression of VEGF and IL-8 [29].

Prevention of metastasis by inhibition of angiogenesis by berberine was confirmed in vivo [87]. In tests on mice, berberine reduced tumor vasculature by inhibiting the activity of factors responsible for angiogenesis, e.g., VEGF, inflammatory mediators: IL-6, IL-1 $\beta$, TNF- $\alpha$ and a factor stimulating the formation of macrophage colonies-GM-CSF (granulocyte macrophage colony-stimulating factor). Berberine was also reported to inhibit the activity of transcription factors responsible for angiogenesis, i.e., NFKB, c-Fos, CREB (cAMP response element-binding protein) and ATF-2 (activating transcription factor 2) [54,82].

\subsection{Inhibition of Epithelial-To-Mesenchymal Transition}

Another facet of the antimetastatic action of berberine is its effect on $\mathrm{E}$ - and $\mathrm{N}$-cadherin. Berberine influences the expression of the E-cadherin and $\mathrm{N}$-cadherin proteins and the effect is time and dose dependent. E-cadherin and $\mathrm{N}$-cadherin are closely related to the migration and invasion of cancer cells. E-kadherin is responsible for the structural integrity of epithelial cells [88]. It is a marker of 
TGF- $\beta 1$-induced epithelial-to-mesenchymal transition. This process leads to increased cell motility. TGF- $\beta$ (transforming growth factor beta 1 ) is a cytokine mediating progression by enhancing the epithelial-to-mesenchymal transition process. Berberine has been proven to inhibit the TGF- $\beta 1$-induced epithelial-to-mesenchymal transition process and an elevated level of E-cadherin is a marker of this process [88]. MMP-2 activates TGF- $\beta$ [89]; hence, the influence of berberine on the process of epithelial-to-mesenchymal transition is probably based on the above-described reduction of the level of metalloproteinase 2 growth factors [90] and the release of growth factors from outside the extracellular matrix, such as TGF- $\beta$ [91,92].

By affecting metalloproteinases, berberine may indirectly influence the occurrence of apoptosis. For example, in human melanoma cells with expressed integrin $\alpha v \beta 3$, the degradation of type I of collagen by MMP- 2 may reveal a binding site with integrin $\alpha v \beta 3$ in these cells. Signaling by this integrin is essential for the viability of melanoma cells and growth in the collagen matrix, thus it potentially protects melanoma cells from apoptosis [81].

MMP inhibitors possess high potential for improving cancer treatment by slowing the process of cancer invasion [79]. Phase I of clinical trials has shown that MMP inhibitors produce minimal adverse side effects. This way, berberine used as a MMP inhibitor seems to be a potential anticancer agent.

\subsection{Anti-Inflammatory Activity}

Anti-inflammatory activity is also one of the important effects rendering berberine a promising anticancer and protective agent. Berberine has anti-inflammatory activity in vitro and in vivo and inhibits the transcription of genes such as IL-1, TNF- and IL-6, decreasing the level of inflammatory proteins. Berberine suppresses the expression of cyclooxygenase 2 and prostaglandin E2 [29]. Studies have also demonstrated that berberine prevents production of IL-8 in tumor cells and blocks the NF- $\mathrm{kb}$ signaling pathway [58]. Studies have shown that berberine also inhibits the elevation of NO and TNF- $\alpha[29,82]$. In colorectal cancer cells, berberine also inhibits COX-2 transcriptional activity, which is significantly increased in this type of cancer [78].

\section{9. $\beta$-Catenin Expression}

Berberine acts on $\beta$-catenin, whose mutations and overexpression are associated with many cancers, including colorectal carcinoma, breast tumors, ovarian and endometrial cancer. In colon cancer cells, the expression of its mRNA, is downregulated by berberine. Berberine efficiently inhibits the nuclear level of $\beta$-catenin by increasing adenomatous polyposis coli protein and $\beta$-catenin interactions [37]. It stimulates the expression of adenomatous polyposis coli protein and regulates $\beta$-catenin negatively $[29,54]$.

\subsection{Inhibition of Carcinogenesis Combined with Metabolism of Lipids}

The influence on the metabolism of fats and lipids is one of the mechanisms of berberine action in the aforementioned metabolic diseases, but it also seems to be very important in malignancies, especially those of the digestive system. It has been described that berberine can act by inducing apoptosis via reduction of FABP expression and accumulation of fatty acids in gastric cancer [93] and by downregulation of key lipogenic enzymes in colon cancer. Berberine targets the SREBP-1 cleavage-activating protein-1/sterol receptor element-binding protein-1 (SCAP/SREBP-1) pathway driving lipogenesis, inhibits the pathway and thus results in downregulation of lipogenic enzymes. Downregulation of key lipogenic enzymes, leading to suppression of lipid synthesis, which is linked to cell proliferation through the Wnt/ $\beta$-catenin pathway, has been described as one of the anticancer mechanisms of berberine [53]. Similarly, the influence on JNK kinases described above is important in anticancer and chemopreventive activity based on the influence on lipid metabolism [94,95].

Anticancer activity of berberine has beed summarised in Table 1. 
Table 1. Molecular mechanisms of anticancer activity of berberine.

\begin{tabular}{|c|c|c|}
\hline Activity & Molecular Targets & References \\
\hline Cell cycle arrest & $\begin{array}{c}\text { Induced G0/G1 phase arrest } \\
\downarrow \text { cyclin B1 expression } \\
\text { Induced G1 phase arrest } \\
\uparrow \text { geneBTG2 expression } \\
\uparrow p 53 \text { protein expression } \\
\downarrow \text { cyclin B1 expression } \\
\uparrow W \text { eel1 expression } \\
\downarrow \text { cyclin D1 expression } \\
\text { Induced G2 phase arrest } \\
\downarrow \text { cyclin B1 expression } \\
\uparrow W e e l 1 \text { expression } \\
\text { Induced G2/M phase arrest } \\
\text { REV3-gene dependent }\end{array}$ & $\begin{array}{c} \\
{[47-49]} \\
{[47,54]} \\
{[47]} \\
{[47,54]} \\
{[55,56]}\end{array}$ \\
\hline Apoptosis induction & $\begin{array}{c}\text { genes } \\
\uparrow C A S P 3 \text { expression } \\
\uparrow C A S P 8 \text { expression } \\
\uparrow C A S P 9 \text { expression } \\
\uparrow B A X \text { expression } \\
\uparrow B A K 1 \text { expression } \\
\uparrow B I K \text { expression } \\
\downarrow \text { BNIP3 expression } \\
\downarrow \text { BNIP1 expression } \\
\downarrow \text { BCL2 expression } \\
\downarrow \text { BCL2L2 expression } \\
\text { proteins } \\
\uparrow \text { caspase-3 expression } \\
\uparrow \text { caspase-9 expression } \\
\uparrow \text { Bax expression } \\
\downarrow \text { Bcl-2 expression } \\
\uparrow p-53 \text { expression } \\
\uparrow \text { Rb expression } \\
\uparrow A T M \text { expression } \\
\text { Caspase-8 expression } \\
\uparrow B I D \text { expression } \\
\uparrow T N F \text { expression } \\
\downarrow \mathrm{C}-\mathrm{IAP} 1 \text { expression } \\
\downarrow \text { XIAP expression } \\
\downarrow \text { Bcl-X expression } \\
\downarrow \text { Survivin expression } \\
\text { TNF-alpha receptors } \\
\uparrow D R 4 \text { activation } \\
\uparrow D R 5 \text { activation }\end{array}$ & $\begin{array}{c}{[22,58,59]} \\
{[54,60]}\end{array}$ \\
\hline
\end{tabular}


Table 1. Cont.

\begin{tabular}{|c|c|c|}
\hline Activity & Molecular Targets & References \\
\hline \multicolumn{3}{|l|}{ Influence on MAPK } \\
\hline \multirow{14}{*}{ cell type depending } & $\uparrow M A P K$ activity & {$[20,21,61]$} \\
\hline & $\uparrow \mathrm{miR}-19 \mathrm{a} / \mathrm{TF} / \mathrm{MAPK}$ pathway activity & \\
\hline & $\uparrow \mathrm{miR}-19 \mathrm{a}$ level & \\
\hline & $\downarrow T F$ level & [21] \\
\hline & $\uparrow E R K 1 / 2$ phosphorylation & [62] \\
\hline & $\downarrow$ ERK1/2 phosphorylation & [19] \\
\hline & $\downarrow$ p38 MAPK phosphorylation & {$[19,62]$} \\
\hline & $\uparrow J N K$ phosphorylation & {$[62]$} \\
\hline & $\downarrow J N K$ phosphorylation & [19] \\
\hline & $\downarrow J N K /$ p38 MAPK pathway activity & [22] \\
\hline & $\uparrow J N K / p 38$ MAPK pathway activity & [20] \\
\hline & $\uparrow$ cell cycle inhibitor p21 (CIP1/WAF1) induction & \\
\hline & $\uparrow p 53$ level & [20] \\
\hline & $\uparrow F O X O 3 a$ induction & \\
\hline \multicolumn{3}{|l|}{ Transcription Regulation } \\
\hline & $\uparrow / \downarrow A P-1$ protein activity (cell type depending) & {$[39,43,78]$} \\
\hline & $\downarrow$ C-fos proto-oncogene expression & [54] \\
\hline \multicolumn{3}{|l|}{ Inhibition of metastasis } \\
\hline & proteins & \\
\hline & $\downarrow$ MMP-2 level & \\
\hline & $\downarrow$ MMP-9 level & {$[54,82,83]$} \\
\hline & $\downarrow$ p-STAT3 phosphorylation & \\
\hline & $\downarrow$ p-STAT3 transfer to nucleus & \\
\hline & $\downarrow$ p-JAK2 phosphorylation & \\
\hline & Interruption of COX2/JAK/STAT signaling pathway & {$[23,29]$} \\
\hline \multicolumn{3}{|l|}{ Inhibition of angiogenesis } \\
\hline & genes & \\
\hline & $\downarrow$ VEGF expression & \\
\hline & $\downarrow C O X-2$ expression & \\
\hline & $\downarrow$ HIF expression & [58] \\
\hline & proteins & \\
\hline & $\downarrow$ VEGR expression and activity & \\
\hline & $\downarrow I \mathrm{IL}-1 \beta$ activity & \\
\hline & $\downarrow$ IL-6 activity & \\
\hline & $\downarrow$ TNF- $\alpha$ activity & \\
\hline & $\downarrow$ GM-CSF activity & \\
\hline & $\downarrow N F-\kappa B$ activity & \\
\hline & $\downarrow c-F o s$ activity & \\
\hline & $\downarrow C R E B$ activity & {$[54,82]$} \\
\hline & $\downarrow \mathrm{PI}-3 \mathrm{~K} / \mathrm{AKT}$ pathway & {$[84]$} \\
\hline \multicolumn{3}{|l|}{$\begin{array}{l}\text { Inhibition of epithelial-to- } \\
\text { mesenchymal transition }\end{array}$} \\
\hline & $\downarrow$ TGF- $\beta 1$ release & \\
\hline & $\uparrow E-c a d h e r i n ~ l e v e l$ & [90-92] \\
\hline
\end{tabular}


Table 1. Cont.

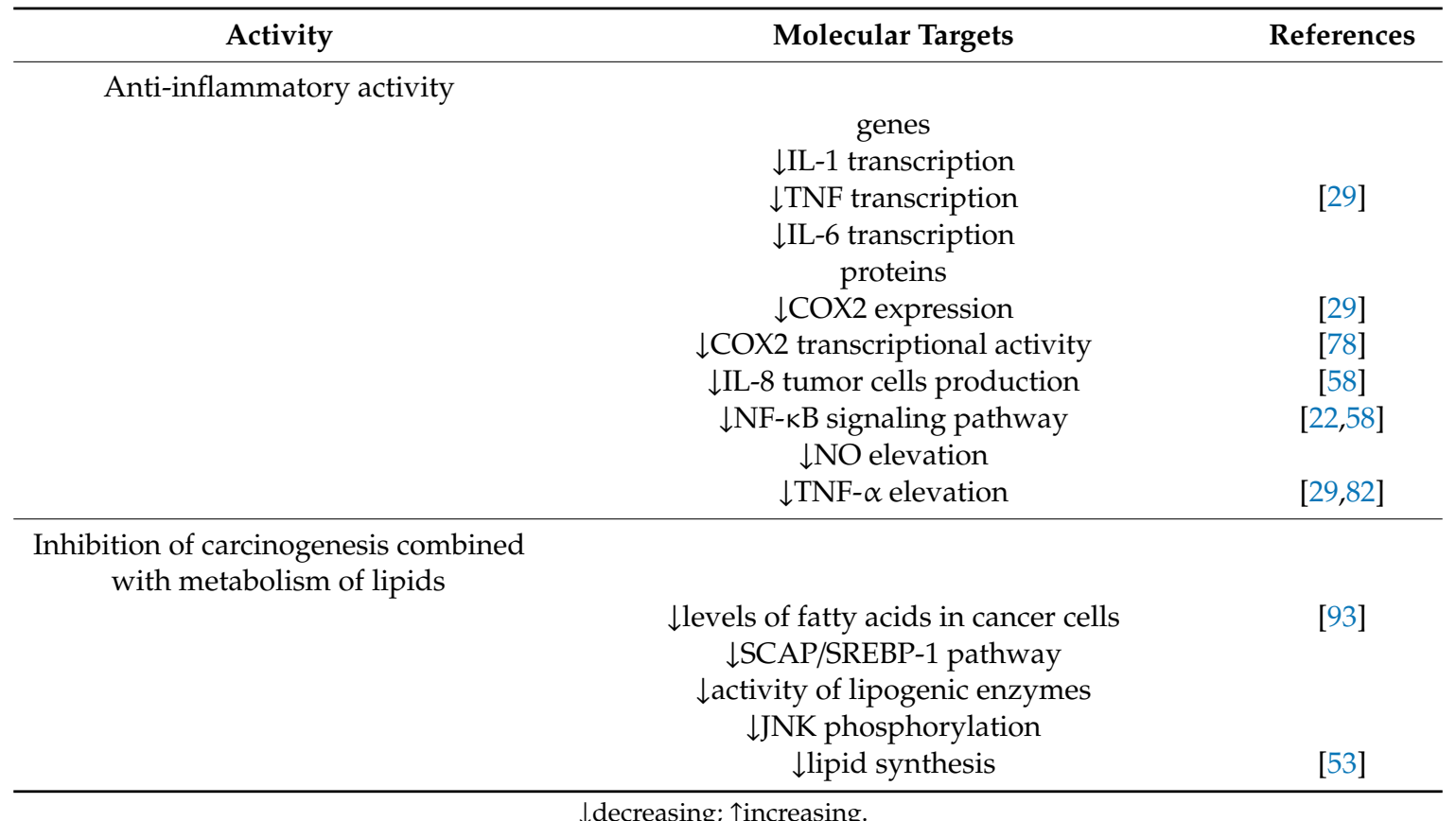

\section{Supportive Action of Berberine-Sensitization and Drug Resistance}

The promising applications of berberine are limited by the poor pharmacokinetics of the compound. Nevertheless, berberine seems to be very effective and possible to use in combined treatment with other chemotherapeutics or therapies. In terms of sensitization, berberine can be considered as a photosensitizing agent in photodynamic therapy. In a study on renal cancer with human renal tubular epithelial cells derived from the normal kidney HK-2 cell line and human cell lines ACHN and the 786-O cell line, berberine increased the level of autophagy and the level of reactive oxygen species. Berberine induced apoptosis in these cells by induction of caspase 3. Low expression of genes of human telomerase reverse transcriptase and vascular endothelial growth factor-D was observed after combined exposure. Furthermore, polo-like kinase 3 exhibited overexpression after treatment with berberine combined with photodynamic therapy [96]. It has also been described that berberine is a promising potential sensitizer for the radiotherapy of hepatocellular carcinoma, where Nrf2, i.e., a master transcription factor in oxidative damage, is required for this effect of berberine $[97,98]$.

Sensitization of breast cancer cells to chemotherapeutics seems to be the most promising approach as regards the sensitizing activity of berberine, but other cells, e.g., hepatocellular carcinoma, leukemic, ovarian and lung cancer cells were also described. In the breast cancer MDA-MB-231 cell line, berberine sensitized cancer cells to methyl methanesulfonate, cisplatin and camptothecin. Simultaneously, no synergistic effects with hydroxurea and olaparib were observed. The mechanism of sensitization is probably based on interference of berberine with DNA repair protein-XRCC1 (X-ray repair cross-complementing protein 1)—mediated base excision. As suggested by Gao et al., this may be a basic mechanism in the use of berberine in the therapy of breast cancer [99].

Combination therapy of berberine and cisplatin markedly enhanced the death of other ovarian cancer cells by inducing necroptosis and apoptosis in the ovarian cancer OVCAR3 cell line and primary ovarian cancer cells with a dose- and time-dependent effect. The apoptosis was caspase-dependent, while the necroptosis accompanied the activation of the RIPK3-MLKL pathway [100]. In combination with gefitinib in non-small-cell lung cancer, berberine inhibits epithelial-mesenchymal transition [101].

The combined treatment with doxorubicine showed in vitro and in vivo reduction of repopulation in hepatocellular carcinoma treatment, achieving a synergic effect inhibiting the Caspase-3-iPLA2-COX-2 pathway [102] and a better therapeutic p53-independent effect than 
doxorubicin alone in leukemic cells [103]. Berberine was found to reverse doxorubicin resistance in MCF-7 and (ADR)-resistant MCF-7 breast cancer cells by inhibiting autophagy, which makes it a promising agent for clinical application in breast cancer treatment. As a suppressor of autophagy, berberine inhibits formation of autophagosome in MCF-7/ADR cells by blocking the accumulation of protein LC3II associated with autophagy. This results in reversal of doxorubicin resistance and reduced cell proliferation. Cellular accumulation of p62 and inhibition of autophagy were also observed. Berberine acted by modulating the PTEN/Akt/mTOR signaling pathway [104].

The supportive activity of berberine in combined treatment is not clarified and needs further research. Importantly, the formulation seems to play a key role. Doxorubicin conjugated to poly (lactic-co-glycolic acid) and used for encapsulation of berberine induced cell cycle arrest in the sub-G1 phase, significant depolarization of the mitochondrial membrane and necrosis in the breast cancer MDA-MB-231 cell line. In vivo studies revealed a very high increase in the half-life and in the plasma drug concentration in such a mode of distribution [105]. Additionally, a nanocarrier hyaluronic acid-conjugated Janus formulation codelivering doxorubicin and berberine exhibited enhanced tumor accumulation and biocompatibility [102]. Maiti et al. described that berberine in combination with curcumin as solid lipid curcumin particles had higher bioavailability and showed higher anticancer effects in cultured cancer cells than in the natural state. In comparison of single and combined treatment of solid lipid curcumin particles and berberine in the human neuroblastoma SH-SY5Y cell line and the human glioblastoma U-87MG and U-251MG cell line, a higher rate of glioblastoma cell death, enhanced fragmentation of DNA, substantially decreased levels of ATP and reduced potential of mitochondrial membrane were observed in the cotreatment of solid lipid curcumin particles and berberine [106].

Novel formulations seem to be crucial in the sensitizing efficacy described above and are important in increasing berberine efficacy itself. For example, the novel berberine complex targeting telomerase appeared to induce dysfunction of mitochondria, damage of the DNA telomere and cell-cycle arrest [107]. Berberine preloaded into folic acid, targeting Janus gold mesoporous silica nanocarriers, exerted a highly potent antitumor effect in patients with liver cancer and ensured good biosafety and effective protection of normal tissues [108]. It is worth mentioning that berberine is a compound with proven ability to bind to G-quadruplexes. Currently, berberine has also been proven to increase the affinity of iminopyrenyl- $\beta$-cyclodextrin for the DNA duplex, which may be important in terms of developing new therapeutic formulations [109].

\section{Preventive Action of Berberine}

The preventive potential of berberine seems to be very promising due to the action towards cancer stem cells and the anti-inflammatory properties of the compound. In combination with d-tri-phenyl-phosphonium at concentrations that are toxic only to cancer cells, berberine effectively decreased transmission of cancer stem cells, which can be important in prevention of many malignancies, as these cells are involved in initiation of tumor and metastatic dissemination and play an important role in cancer therapy resistance [110].

As described in research on colon cancer, berberine can be considered as a preventive agent due to its supportive action in colitis leading to colon cancer in $5 \%$ of patients with this disease. Berberine markedly decreased the Geboes grade in colitis in vivo. On the other hand, it had an insignificant effect on other tissues or blood markers related to inflammation and cell growth, while the combination of mesalamine and berberine enhanced the anti-inflammatory effects of mesalamine on colonic tissue in patients with ulcerative colitis [111]. On the other hand, other authors suggest that the anti-inflammatory activities of berberine itself make it an opportunity to prevent cancers associated with inflammation such as colorectal cancer [112].

\section{Challenge to New Derivatives and Formulations of Berberine}

Although chloride or sulphate salts of berberine are better soluble and are therefore used clinically [3], the low bioavailability and poor pharmacokinetic parameters of berberine are still the 
main challenge in its the potential usage. Next to novel formulations, development of new derivatives with similar biological activity based on the same mechanisms but not limited by low pharmacological parameters seems to be the most important target. Compounds based on berberine that will be effective at lower concentrations and have stronger biological activity are currently being intensively investigated. Especially the latest papers from 2019 and 2020 provide information on derivatives, giving a promising view, as a significant relationship between structure and activity was observed [113]. New derivatives exhibit similar parameters of biological activity and are promising for further research [114].

To date, berberine-12-amine derivatives have been evaluated in terms of the inhibition of the growth of human cancer cell lines. Quaternary 12-aminoberberine chloride, quaternary 12-nitroberberine chloride, tertiary 12-aminotetrahydroberberine and 12-aminoberberine derivatives with different states of reduction showed growth inhibition activities in human cancer cells: colorectal cell line HCT-8, gastric cancer cell line BGC-823, liver cancer cell line Bel7402, cervical cancer cell line HeLa and lung cancer cell line A549. Quaternary berberine-12-N,N-di-n-alkylamine chlorides are significantly stronger than reduced counterparts. The activities increased with the elongation of the n-alkyl carbon chain of $12-\mathrm{N}, \mathrm{N}$-di-n-alkylamino in the range of about 6-8 carbon atoms. The activities decreased with the elongation of the n-alkyl carbon chain when the carbon atom numbers exceeded $6-8$. The activities of the tertiary amine structure were significantly higher than that of the secondary amine structure [113].

13-alkyl-substituted derivatives of berberine are more active than berberine itself towards human cancer cell lines. In radiotherapy-resistant MDA-MB-231 cells, there were lower levels of proapoptotic genes and higher levels of antiapoptotic genes than in the breast cancer MDA-MB-231 cell line treated with 13-ethylberberine. In both cell lines, reduced proliferation and colony-formation was described after exposure to this derivative. 13-ethylberberine induced apoptosis by promoting mitochondrial and intracellular reactive oxygen species and by regulating proteins involved in the intrinsic pathway of apoptosis but not in the extrinsic apoptosis pathway. Such derivatives occurred to be similarly effective and seem to be candidates in therapeutic strategies characteristic for berberine but exact comparison to berberine in terms of bioavailability and distribution are still needed [115].

The synthesis and analysis of 9-O-substituted derivatives of berberine also gave promising effects. Berberine derivative (9-(3-bromopropoxy)-10-methoxy-5,6-dihydro-[1,3]dioxolo[4,5-g]isoquino[3,2-a] isoquinolin-7-ylium bromide) was found to have 30-fold higher antiproliferative activity and 6-fold higher apoptosis-inducing activity in leukemia cells, compared to berberine [116].

Additionally, the assessment of berberine derivatives with cis-substituents at positions $\mathrm{C} 9$ and $\mathrm{C} 13[117,118]$ or 13-[CH2CO-Cys-(Bzl)-OBzl]-berberine [119] and a series of berberine derivatives with modified position 9-O [120,121] was described. The methylene-dioxy and methoxyl groups in berberine seem to be especially important for the anticancer activity exhibited by its derivatives [122].

The absorption of bioactive berberine (Quillaja extract emulsified berberine) in humans is in the recruiting phase of a currently running clinical trial [123].

\section{Berberine in Clinical Trials}

Due to the wide range of effects and safety, berberine has been assessed clinically. There are many ongoing trials (Table 2) and even more interesting ones are going to start soon. Berberine was clinically assessed in schizophrenia and its metabolic and cardiovascular effects were assessed in the metabolic syndrome, obesity, diabetes mellitus type 2 and insulin-resistance. The compound was clinically assessed in non-alcoholic fatty liver disease, dyslipidemia and hypercholesterolemia. It was also clinically assessed in cases of colorectal adenoma, gastric ulcer, chronic gastritis and gastric cancer [54]. Its anticancer activity was studied to assess mitigation of the effects of radiation therapy in the treatment in patients with lymphoma and cervical cancer. In patients with non-small cell lung cancer during radiation therapy, berberine was found to protect lung cells from ionized radiation-induced damage [42]. In patients with glioma, it selectively sensitized tumor cells to ionizing radiation, while healthy cells remained at the same level of sensitivity [87]. There are many completed 
clinical trials assessing berberine. The main target is its activity lowering cholesterol and glucose levels. The nutraceutical potential of berberine combined with some natural compounds seems to be very interesting.

In patients with type 2 diabetes mellitus berberine significantly improved the level of fasting blood glucose, the level of postprandial blood glucose and the level of glycosylated hemoglobin and decreased insulin resistance. It has been estimated that berberine exerts a beneficial effect on blood glucose control comparable to that of metformin. Berberine appears to have an advantage over rosiglitazone in improving the level of fasting blood glucose. The combination therapy of berberine with oral hypoglycemic drugs may arouse high hopes. However, the efficacy of berberine should be further evaluated in a larger patient population of patients with type 2 diabetes mellitus [124].

As a nutraceutical, berberine with chromium picolinate, inositol, curcumin and banaba was clinically assessed in patients with fasting dysglycemia. It was reported to be helpful in improving glyco-metabolic compensation and total cholesterol and triglyceride value and in reducing inflammatory status in patients with dysglycemia. Reduced fasting and post-prandial level of glucose in plasma was observed after administration of the nutraceuticals. There was also a decrease in the level of fasting plasma insulin and in the level of glycated hemoglobin. Moreover, in patients with fasting dysglycemia after 3 months of application of combined nutraceutical therapy, the level of high-sensitivity C-reactive protein was reduced [125]. Furthermore, berberine was clinically assessed in metabolic syndrome. In metabolic syndrome in schizophrenia, the effect of berberine administration on insulin secretion, insulin sensitivity and metabolic syndrome was evaluated. A significant decrease in waist circumference and remission of the presence of metabolic syndrome was noted in patients after the administration of berberine. A marked decrease in systolic blood pressure, triglycerides, area under the curve of glucose, area under the curve of insulin and insulinogenic index and an increase in the Matsuda index were reported. According to the clinical trials, administration of berberine abolishes the metabolic syndrome and decreases waist circumference. It also decreases insulin secretion and the levels of triglycerides Simultaneously, it increases insulin sensitivity in patients with metabolic syndrome in schizophrenia [126]. Additionally, the hypoglycemic effect of berberine and bifidobacterial administration in patients with prediabetes or diabetes mellitus was assessed and it was proved that berberine and bifidobacteria may be supportive in the treatment of diabetes [127].

An important and clinically assessed aspect of berberine activity is its cholesterol lowering effect. The efficacy and safety of a nutraceutical combination consisting mainly of red yeast rice extract, berberine and policosanols were assessed in patients with low to moderate risk of hypercholesterolemia. This combination associated with a hypolipidemic diet reduced total cholesterol and LDL-C levels [128]. Assessed in non-alcoholic fatty liver disease, comparison of berberine supplementation to lifestyle intervention and berberine treatment plus lifestyle intervention resulted in a strong reduction of hepatic fat content accompanied by improvement in serum lipid profiles and body weight. Berberine reduced body weight and the lipid profile more effectively than pioglitazone. The adverse events were mild and mainly affected the digestive system. Berberine was clinically proved to improve parameters in patients with non-alcoholic fatty liver disease and related metabolic disorders. Its therapeutic effect may involve regulation of hepatic lipid metabolism [129]. The compound has also been evaluated clinically in menopausal women at risk of dyslipidemia. In combination with compounds of plant origin such as chlorogenic acid and tocotrienols, a reduction in LDL and total cholesterol levels was observed after three months of supplementation; however, the influence of berberine on menopausal symptoms requires further research [130]. 
Table 2. Currently running and active clinical trials based on: https://clinicaltrials.gov.

\begin{tabular}{|c|c|c|c|c|c|c|c|c|}
\hline Title & Status & Conditions & Interventions & Phase & Measures & Enrollment & Age (Years) & Completion: \\
\hline $\begin{array}{l}\text { A Research of Berberine } \\
\text { Hydrochloride to Prevent } \\
\text { Colorectal Adenomas in } \\
\text { Patients with Previous } \\
\text { Colorectal Cancer }\end{array}$ & Recruiting & $\begin{array}{l}\text { Colorectal } \\
\text { Adenomas }\end{array}$ & $\begin{array}{c}\text { Berberine } \\
\text { hydrochloride } \\
\text { and Placebo }\end{array}$ & Phase 2 Phase 3 & $\begin{array}{l}\text { Cumulative colorectal adenoma } \\
\text { incidence rate during Berberine } \\
\text { hydrochloride or placebo treatment } \\
\text { in patients with a history of } \\
\text { colorectal cancer } \\
\text { - Cumulative numbers or diameters } \\
\text { of new colorectal adenomas during } \\
\text { Berberine hydrochloride or placebo } \\
\text { treatment in patients with a history } \\
\text { of colorectal cancer }\end{array}$ & 1000 & $18-80$ & March 2021 \\
\hline $\begin{array}{l}\text { Comparison of Berberine } \\
\text { and Metformin for the } \\
\text { Treatment for MS in } \\
\text { Schizophrenia Patients }\end{array}$ & Recruiting & $\begin{array}{l}\text { Schizophrenia } \\
\text { Metabolic } \\
\text { Syndrome }\end{array}$ & $\begin{array}{l}\text { Berberine } \\
\text { Metformin }\end{array}$ & Phase 4 & $\begin{array}{ll}\text { - } & \text { Fasting blood samples for Fasting } \\
& \text { blood glucose } \\
\text { - } & \text { Triglyceride } \\
\text { - } & \text { High-Density Lipoprotein } \\
\text { - } & \text { Waist circumference } \\
\text { - } & \text { Blood pressure including systolic } \\
& \text { and diastolic pressure } \\
\text { - } & \text { Body mass index } \\
\text { - } & \text { Total Cholesterol } \\
\text { - } & \text { C reactive protein } \\
\text { - } & \text { Interleukin-1,Interleukin-6,tumor } \\
& \text { necrosis factor(TNF) }\end{array}$ & 100 & $18-65$ & December 2019 \\
\hline $\begin{array}{c}\text { Primary } \\
\text { Chemoprevention of } \\
\text { Familial Adenomatous } \\
\text { Polyposis with Berberine } \\
\text { Hydrochloride }\end{array}$ & Recruiting & $\begin{array}{l}\text { Colorectal } \\
\text { Adenomas }\end{array}$ & $\begin{array}{c}\text { Berberine } \\
\text { hydrochloride } \\
\text { Placebo }\end{array}$ & Phase 2 Phase 3 & $\begin{array}{l}\text { Cumulative numbers and diameters } \\
\text { of colorectal adenomas during } \\
\text { Berberine hydrochloride or placebo } \\
\text { treatment in patients with familial } \\
\text { adenomatous polyposis }\end{array}$ & 100 & $18-65$ & December 2020 \\
\hline $\begin{array}{l}\text { Effect of Berberine Versus } \\
\text { Metformin on Glycemic } \\
\text { Control, Insulin } \\
\text { Sensitivity and Insulin } \\
\text { Secretion in Prediabetes }\end{array}$ & $\begin{array}{c}\text { Active, not } \\
\text { recruiting }\end{array}$ & $\begin{array}{c}\text { Prediabetes } \\
\text { Impaired } \\
\text { Fasting Glucose } \\
\text { Impaired } \\
\text { Glucose } \\
\text { Tolerance }\end{array}$ & $\begin{array}{l}\text { Berberine } \\
\text { Metformin }\end{array}$ & Phase 4 & $\begin{array}{ll} & \text { Fasting glucose levels } \\
\text { - } & \text { postprandial glucose levels } \\
\text { - } & \text { Glycosylated hemoglobin } \\
\text { - } & \text { Total insulin secretion } \\
\text { - } & \text { First phase of insulin secretion } \\
\text { - } & \text { Insulin sensitivity } \\
\text { - } & \text { Body Weight } \\
\text { - } & \text { Body Mass Index } \\
\text { - } & \text { Body fat percentage } \\
\text { - } & \text { Waist circumference } \\
\text { - } & \text { and } 8 \text { more }\end{array}$ & 28 & $31-60$ & August 2020 \\
\hline
\end{tabular}


Table 2. Cont

\begin{tabular}{|c|c|c|c|c|c|c|c|c|}
\hline Title & Status & Conditions & Interventions & Phase & Measures & Enrollment & Age (Years) & Completion: \\
\hline $\begin{array}{l}\text { Effect of Berberine for } \\
\text { Endothelial Function and } \\
\text { Intestinal Microflora in } \\
\text { Patients with Coronary } \\
\text { Artery Disease }\end{array}$ & $\begin{array}{l}\text { Active, not } \\
\text { recruiting }\end{array}$ & $\begin{array}{l}\text { Stable Coronary } \\
\text { Artery Disease } \\
\text { Percutaneous } \\
\text { Coronary } \\
\text { Intervention }\end{array}$ & $\begin{array}{l}\text { Berberine } \\
\text { Aspirin } \\
\text { Clopidogrel } \\
\text { Statin }\end{array}$ & $\begin{array}{l}\text { Phase } 1 \\
\text { Phase } 2\end{array}$ & $\begin{array}{ll}\text { - } & \text { Endothelial function measured by } \\
& \text { flow mediated dilation } \\
\text { - } & \text { Gut microbiome } \\
\text { - } & \text { Fecal metabolomics } \\
& \text { profile measurement } \\
\text { - } & \text { Blood lipid levels } \\
-\quad \text { Inflammatory factor levels } \\
\text { - } \quad \text { Blood glucose levels } \\
\end{array}$ & 24 & $18-75$ & December 2020 \\
\hline $\begin{array}{c}\text { A Mechanistic } \\
\text { Randomized Controlled } \\
\text { Trial on the } \\
\text { Cardiovascular Effect of } \\
\text { Berberine }\end{array}$ & Recruiting & $\begin{array}{l}\text { Cardiovascular } \\
\text { Risk Factor }\end{array}$ & $\begin{array}{l}\text { Berberine } \\
\text { Placebo }\end{array}$ & $\begin{array}{l}\text { Phase } 2 \\
\text { Phase } 3\end{array}$ & $\begin{array}{ll}\text { - } & \text { lipid profile } \\
\text { - } & \text { blood pressure } \\
\text { - } & \text { thromboxane A2 } \\
\text { - } & \text { testosterone } \\
\text { - } & \text { body mass index } \\
\text { - } & \text { waist hip ratio } \\
\text { - } & \text { fasting glucose } \\
\text { - } & \text { liver funsulion } \\
\end{array}$ & 84 & $20-65$ & June 2020 \\
\hline $\begin{array}{l}\text { Combination of Danazole } \\
\text { With Berberine in the } \\
\text { Treatment of ITP }\end{array}$ & $\begin{array}{l}\text { Active, not } \\
\text { recruiting }\end{array}$ & $\begin{array}{l}\text { Corticosteroid-resistant } \\
\text { or Relapsed ITP }\end{array}$ & $\begin{array}{l}\text { Berberine plus } \\
\text { danazol }\end{array}$ & Phase 2 & $\begin{array}{l}\text { - The Count of Participants That } \\
\text { Achieved 6-month } \\
\text { Sustained Response } \\
\text { - the Count of Participants That Had } \\
\text { Adverse Events } \\
\text { - the Count of Participants That } \\
\text { Achieved Initial Response }\end{array}$ & 55 & $18-80$ & June 2021 \\
\hline $\begin{array}{l}\text { Antiplatelet Effect of } \\
\text { Berberine in Patients } \\
\text { After Percutaneous } \\
\text { Coronary Intervention }\end{array}$ & Recruiting & $\begin{array}{l}\text { Coronary Artery } \\
\text { Disease } \\
\text { Percutaneous } \\
\text { Coronary } \\
\text { Intervention }\end{array}$ & $\begin{array}{l}\text { Berberine } \\
\text { Standard } \\
\text { treatment } \\
\text { Aspirin } \\
\text { Clopidogrel }\end{array}$ & Phase 4 & $\begin{array}{l}\text { P2Y12 reaction unit } \\
\begin{array}{l}\text { - } \\
\text { - }\end{array} \text { Uratelet reactivity index } \\
\quad \text { B2 (11-dHTXB2) }\end{array}$ & 64 & $18-70$ & December 2020 \\
\hline
\end{tabular}


Table 2. Cont.

\begin{tabular}{|c|c|c|c|c|c|c|c|c|}
\hline Title & Status & Conditions & Interventions & Phase & Measures & Enrollment & Age (Years) & Completion: \\
\hline $\begin{array}{l}\text { Berberine Chloride in } \\
\text { Preventing Colorectal } \\
\text { Cancer in Patients with } \\
\text { Ulcerative Colitis in } \\
\text { Remission }\end{array}$ & $\begin{array}{l}\text { Active, not } \\
\text { recruiting }\end{array}$ & $\begin{array}{c}\text { Ulcerative } \\
\text { Colitis }\end{array}$ & $\begin{array}{l}\text { Berberine } \\
\text { Chloride } \\
\text { Placebo }\end{array}$ & Phase 1 & $\begin{array}{ll}- & \text { Incidence of organ toxicity } \\
\text { - } & \text { Clinical efficacy of berberine } \\
\text { chloride measured using the } \\
\text { UCDAI score } \\
\text { - } \quad \text { plasma markers of inflammation } \\
\text { colorectal tissue } \\
\text { biomarkers expression } \\
\text { - } \quad \text { gene methylation status } \\
\text { blood berberine } \\
\text { chloride concentration } \\
\text { - Severity of histologic inflammation }\end{array}$ & 18 & $18-70$ & December 2020 \\
\hline $\begin{array}{c}\text { Berberine Prevent } \\
\text { Contrast-induced } \\
\text { Nephropathy in Patients } \\
\text { With Diabetes }\end{array}$ & Recruiting & $\begin{array}{c}\text { Diabetes } \\
\text { Mellitus } \\
\text { Chronic } \\
\text { Kidney Disease }\end{array}$ & Berberine & Phase 4 & $\begin{array}{l}\text { - } \quad \text { Contrast-induced nephropathy } \\
\text { - } \quad \text { Major adverse renal events }\end{array}$ & 800 & 18 and older & December 2020 \\
\hline $\begin{array}{l}\text { Berberine as Adjuvant } \\
\text { Treatment for } \\
\text { Schizophrenia Patients }\end{array}$ & Recruiting & $\begin{array}{c}\text { Schizophrenia } \\
\text { Spectrum and } \\
\text { Other Psychotic } \\
\text { Disorders } \\
\text { Metabolic } \\
\text { Syndrome x }\end{array}$ & $\begin{array}{l}\text { Berberine } \\
\text { Placebos } \\
\text { Antipsychotic } \\
\text { Agents }\end{array}$ & Phase 2 Phase 3 & $\begin{array}{l}\text { Weight gain } \\
\text { - Changes in body mass index } \\
\text { - Changes in waist circumference } \\
\text { - Changes in blood pressure } \\
\text { - Changes in triglycerides } \\
\text { - Changes in total cholesterol } \\
\quad \text { high-densing lipoprotein } \\
\text { - Changes in low-density lipoprotein } \\
\text { - Changes in fasting glucose } \\
\text { - Changes in insulin }\end{array}$ & 120 & $18-65$ & May 2021 \\
\hline $\begin{array}{c}\text { Evaluating the } \\
\text { Tolerability and Effects of } \\
\text { Berberine on Major } \\
\text { Metabolic Biomarkers: A } \\
\text { Pilot Study }\end{array}$ & Recruiting & $\begin{array}{l}\text { Metabolic } \\
\text { Syndrome }\end{array}$ & $\begin{array}{l}\text { Berberine } \\
\text { Identical } \\
\text { Placebo }\end{array}$ & Not Applicable & $\begin{array}{l}\text { LDL Cholesterol } \\
\text { - Hemoglobin A1c } \\
\text { - } \quad \text { Number of participants with } \\
\text { adverse events }\end{array}$ & 40 & 18 and older & December 2021 \\
\hline
\end{tabular}


Table 2. Cont

\begin{tabular}{|c|c|c|c|c|c|c|c|c|}
\hline Title & Status & Conditions & Interventions & Phase & Measures & Enrollment & Age (Years) & Completion: \\
\hline $\begin{array}{l}\text { Efficacy and Safety of } \\
\text { Berberine in } \\
\text { Non-alcoholic } \\
\text { Steatohepatitis }\end{array}$ & Recruiting & $\begin{array}{l}\text { Non-alcoholic } \\
\text { Steatohepatitis }\end{array}$ & $\begin{array}{c}\text { Behavioral: } \\
\text { Lifestyle Placebo }\end{array}$ & Phase 4 & $\begin{array}{l}\text { - Improvement in histologic features } \\
\text { of nonalcoholic steatohepatitis by } \\
\text { NAFLD activity score } \\
\text { - } \quad \text { Improvement in the composites of } \\
\text { NAFLD activity scores for steatosis, } \\
\text { lobular inflammation, } \\
\text { hepatocellular ballooning } \\
\text { - Improvement in liver histological } \\
\text { fibrosis staging } \\
\text { - Resolution of NASH } \\
\text { - } \quad \text { anthropometric measures } \\
\text { - } \\
\text { - liver fat content } \\
\text { serum cytokeratin } 18(\mathrm{CK}-18) \text { in } \\
\text { U/L }\end{array}$ & 120 & $18-75$ & July 2021 \\
\hline $\begin{array}{l}\text { Study on the Efficacy and } \\
\text { Gut Microbiota of } \\
\text { Berberine and Probiotics } \\
\text { in Patients with Newly } \\
\text { Diagnosed Type } 2 \\
\text { Diabetes }\end{array}$ & $\begin{array}{l}\text { Active, not } \\
\text { recruiting }\end{array}$ & Type 2 Diabetes & $\begin{array}{c}\text { Berberine } \\
\text { hydrochloride } \\
\text { ProMetS } \\
\text { probiotics powder }\end{array}$ & Phase 3 & $\begin{array}{ll}\text { - } & \text { HbA1c } \\
\text { - } & \text { Gut microbiome } \\
\text { - } & \text { Fasting glucose levels } \\
\text { - } & \text { Fasting insulin levels } \\
\text { - } & \text { 2-h postprandial insulin levels } \\
\text { - } & \text { Serum Triglycerides } \\
\text { - } & \text { Serum total Cholesterol } \\
\text { - } & \text { Serum HDL-c } \\
\end{array}$ & 400 & $20-69$ & May 2019 \\
\hline $\begin{array}{l}\text { Effect of Mebo Dressing } \\
\text { Versus Standard Care on } \\
\text { Managing Donor and } \\
\text { Recipient Sites of } \\
\text { Split-thickness Skin Graft }\end{array}$ & Recruiting & Burns & $\begin{array}{l}\text { Moist Exposed } \\
\text { Burn Ointment } \\
\text { (MEBO-sesame } \\
\text { oil, beta-sitosterol, } \\
\text { berberine and } \\
\text { other small } \\
\text { quantities of plant } \\
\text { ingredients) }\end{array}$ & Phase 1 & $\begin{array}{l}\text { Wound Healing Assessment Recovery } \\
\text { Time } \\
\text { - } \quad \text { Rate of Infections } \\
\text { - } \quad \text { Pain Assessment } \\
\text { - } \quad \text { Total Treatment Costs } \\
\text { - } \quad \text { Rate of Complications } \\
\text { Quality of Life }\end{array}$ & 40 & $2-60$ & July 2019 \\
\hline
\end{tabular}


Berberine-containing quadruple therapy was assessed as an alternative treatment for Helicobacter pylori eradication was assessed in comparison to bismuth-based quadruple regimen, which is an alternative for Helicobacter pylori eradication due to the increasing antimicrobial resistance. The eradication rates in berberine groups were at a similar level as in the bismuth group. There was also no statistically significant difference in the incidence of adverse events. Therefore, berberine can be an alternative for Helicobacter pylori eradication [131].

The chemopreventive potential of colorectal adenoma prevention and recurrence was assessed clinically. Patients with colorectal adenomas subjected to complete polypectomy received berberine twice daily. The treatment proved to be safe and effective. Reduced risk of recurrence of colorectal adenoma was found, showing berberine as an option for chemoprevention after polypectomy [127].

Currently, berberine is at the stage of clinical trials with its cardiovascular and metabolic effects. It is clinically compared with metformin as an agent in therapy for metabolic syndrome in patients with schizophrenia and clinically assessed as an adjuvant treatment for patients with schizophrenia and its spectrum, patients with other psychotic disorders or metabolic syndrome X. Berberine is in clinical trials assessing its suitability for hyperglycemic clamp, in diabetes mellitus and as a preventive agent in induced nephropathy in patients with Type 2 diabetes mellitus accompanied by chronic kidney disease. The beneficial berberine effects on the risk factors of cardiovascular diseases and its antiplatelet effect are clinically assessed in patients after elective percutaneous coronary intervention in coronary artery disease. In oncological patients, berberine is currently being assessed as a preventive agent in patients with colorectal adenomas with previous colorectal cancer treated with gefitinib. In the nearest future, berberine will be clinically studied in patients with lung adenocarcinoma, corticosteroid-resistant or relapsed immune thrombocytopenic purpura and patients with graft pain and gingival recession. Trials with diabetic patients will be continued as well [123].

\section{Summary}

Berberine is one of the most interesting and promising natural agents currently due to its proven biological activity, especially in biochemical pathways important in apoptosis, carcinogenesis and metastasis. As a natural compound with low toxicity towards healthy cells, berberine shows great potency in the treatment of many clinical stages, e.g., metabolic disorders and related symptoms, inflammation and its after-effects, or cancer prevention and combined cancer treatment. However, there are limitations in the dissolution, absorption and biodistribution of berberine. Currently, development of new formulations and new derivatives is a very important trend in berberine research to overcome its limitations in clinical application [34,132].

Author Contributions: All authors contributed to writing and editing the manuscript. All authors have read and agreed to the published version of the manuscript.

Funding: This research received no external funding.

Acknowledgments: Authors are thankful to Medical University of Lublin for supporting the present study.

Conflicts of Interest: The authors declare no conflict of interest.

\section{References}

1. Feng, X.; Sureda, A.; Jafari, S.; Memariani, Z.; Tewari, D.; Annunziata, G.; Barrea, L.; Hassan, S.T.S.; Šmejkal, K.; Malaník, M.; et al. Berberine in Cardiovascular and Metabolic Diseases: From Mechanisms to Therapeutics. Theranostics 2019, 9, 1923-1951. [CrossRef]

2. Wang, Y.; Zidichouski, J.A. Update on the Benefits and Mechanisms of Action of the Bioactive Vegetal Alkaloid Berberine on Lipid Metabolism and Homeostasis. Cholesterol 2018, 2018, 7173920. [CrossRef]

3. Fan, J.; Zhang, K.; Jin, Y.; Li, B.; Gao, S.; Zhu, J.; Cui, R. Pharmacological effects of berberine on mood disorders. J. Cell. Mol. Med. 2019, 23, 21-28. [CrossRef] [PubMed]

4. Zeng, X.-H.; Zeng, X.-J.; Li, Y.-Y. Efficacy and safety of berberine for congestive heart failure secondary to ischemic or idiopathic dilated cardiomyopathy. Am. J. Cardiol. 2003, 92, 173-176. [CrossRef] 
5. Barrios, V.; Escobar, C.; Cicero, A.F.G.; Burke, D.; Fasching, P.; Banach, M.; Bruckert, E. A nutraceutical approach (Armolipid Plus) to reduce total and LDL cholesterol in individuals with mild to moderate dyslipidemia: Review of the clinical evidence. Atheroscler. Suppl. 2017, 24, 1-15. [CrossRef] [PubMed]

6. Li, X.-Y.; Zhao, Z.-X.; Huang, M.; Feng, R.; He, C.-Y.; Ma, C.; Luo, S.-H.; Fu, J.; Wen, B.-Y.; Ren, L.; et al. Effect of Berberine on promoting the excretion of cholesterol in high-fat diet-induced hyperlipidemic hamsters. J. Transl. Med. 2015, 13, 278. [CrossRef] [PubMed]

7. Brusq, J.-M.; Ancellin, N.; Grondin, P.; Guillard, R.; Martin, S.; Saintillan, Y.; Issandou, M. Inhibition of lipid synthesis through activation of AMP kinase: An additional mechanism for the hypolipidemic effects of berberine. J. Lipid Res. 2006, 47, 1281-1288. [CrossRef]

8. Wang, L.; Peng, L.; Wei, G.; Ge, H. Therapeutic Effects of Berberine Capsule on Patients with Mild Hyperlipidemia. Zhongguo Zhong Xi Yi Jie He Za Zhi Zhongguo Zhongxiyi Jiehe Zazhi Chin. J. Integr. Tradit. West. Med. 2016, 36, 681-684.

9. Wang, H.; Zhu, C.; Ying, Y.; Luo, L.; Huang, D.; Luo, Z. Metformin and berberine, two versatile drugs in treatment of common metabolic diseases. Oncotarget 2017, 9, 10135-10146. [CrossRef]

10. An, Y.; Sun, Z.; Zhang, Y.; Liu, B.; Guan, Y.; Lu, M. The use of berberine for women with polycystic ovary syndrome undergoing IVF treatment. Clin. Endocrinol. 2014, 80, 425-431. [CrossRef]

11. Li, C.; Guan, X.-M.; Wang, R.-Y.; Xie, Y.-S.; Zhou, H.; Ni, W.-J.; Tang, L.-Q. Berberine mitigates high glucose-induced podocyte apoptosis by modulating autophagy via the mTOR/P70S6K/4EBP1 pathway. Life Sci. 2020, 243, 117277. [CrossRef] [PubMed]

12. Li, Y.; Kuang, H.; Shen, W.; Ma, H.; Zhang, Y.; Stener-Victorin, E.; Hung, E.; Ng, Y.; Liu, J.; Kuang, H.; et al. Letrozole, berberine, or their combination for anovulatory infertility in women with polycystic ovary syndrome: Study design of a double-blind randomised controlled trial. BMJ Open 2013, 3, e003934. [CrossRef] [PubMed]

13. Li, M.-F.; Zhou, X.-M.; Li, X.-L. The Effect of Berberine on Polycystic Ovary Syndrome Patients with Insulin Resistance (PCOS-IR): A Meta-Analysis and Systematic Review. Evid. Based Complement. Altern. Med. 2018, 2018, 2532935. [CrossRef] [PubMed]

14. Wu, X.-K.; Wang, Y.-Y.; Liu, J.-P.; Hou, L.-H.; Gao, Y.-Q.; Du, S.-M.; Yan, Y.; Zhang, J.-F.; Xue, H.-Y.; Li, W.-L.; et al. Letrozole, berberine, or a combination for infertility in Chinese women with polycystic ovary syndrome: A multicentre, randomised, double-blind, placebo-controlled trial. Lancet 2015, 386, S70. [CrossRef]

15. Cicero, A.F.G.; Reggi, A.; Parini, A.; Morbini, M.; Rosticci, M.; Grandi, E.; Borghi, C. Berberine and Monacolin Effects on the Cardiovascular Risk Profile of Women with Oestroprogestin-Induced Hypercholesterolemia. High Blood Press. Cardiovasc. Prev. 2014, 21, 221-226. [CrossRef]

16. Hu, X.; Zhang, Y.; Xue, Y.; Zhang, Z.; Wang, J. Berberine is a potential therapeutic agent for metabolic syndrome via brown adipose tissue activation and metabolism regulation. Am. J. Transl. Res. 2018, 10, 3322-3329.

17. Kumar, R.; Awasthi, M.; Sharma, A.; Padwad, Y.; Sharma, R. Berberine induces dose-dependent quiescence and apoptosis in A549 cancer cells by modulating cell cyclins and inflammation independent of mTOR pathway. Life Sci. 2020, 244, 117346. [CrossRef]

18. Bogoyevitch, M.A.; Boehm, I.; Oakley, A.; Ketterman, A.J.; Barr, R.K. Targeting the JNK MAPK cascade for inhibition: Basic science and therapeutic potential. Biochim. Biophys. Acta 2004, 1697, 89-101. [CrossRef]

19. Li, H.-L.; Wu, H.; Zhang, B.-B.; Shi, H.-L.; Wu, X.-J. MAPK pathways are involved in the inhibitory effect of berberine hydrochloride on gastric cancer MGC 803 cell proliferation and IL-8 secretion in vitro and in vivo. Mol. Med. Rep. 2016, 14, 1430-1438. [CrossRef]

20. Zheng, F.; Tang, Q.; Wu, J.; Zhao, S.; Liang, Z.; Li, L.; Wu, W.; Hann, S. p38 $\alpha$ MAPK-mediated induction and interaction of FOXO3a and p53 contribute to the inhibited-growth and induced-apoptosis of human lung adenocarcinoma cells by berberine. J. Exp. Clin. Cancer Res. 2014, 33, 36. [CrossRef]

21. Chen, Q.; Shi, J.; Ding, Z.; Xia, Q.; Zheng, T.; Ren, Y.; Li, M.; Fan, L. Berberine induces apoptosis in non-small-cell lung cancer cells by upregulating miR-19a targeting tissue factor. Cancer Manag. Res. 2019, 11, 9005-9015. [CrossRef] [PubMed]

22. Wang, Y.; Zhou, M.; Shang, D. Berberine inhibits human gastric cancer cell growth via deactivation of p38/JNK pathway, induction of mitochondrial-mediated apoptosis, caspase activation and NF- $\mathrm{kB}$ inhibition. J. BUON Off. J. Balk. Union Oncol. 2020, 25, 314-318. 
23. Lin, X.; Zhang, N. Berberine: Pathways to protect neurons. Phytother. Res. 2018, 32, 1501-1510. [CrossRef] [PubMed]

24. Singh, N.; Sharma, B. Toxicological Effects of Berberine and Sanguinarine. Front. Mol. Biosci. $2018,5$. [CrossRef] [PubMed]

25. Kulkarni, S.K.; Dhir, A. Berberine: A plant alkaloid with therapeutic potential for central nervous system disorders. Phytother. Res. 2010, 24, 317-324. [CrossRef]

26. Ahmed, T.; Gilani, A.-H.; Abdollahi, M.; Daglia, M.; Nabavi, S.F.; Nabavi, S.M. Berberine and neurodegeneration: A review of literature. Pharmacol. Rep. 2015, 67, 970-979. [CrossRef]

27. Song, B.; Tang, X.; Wang, X.; Huang, X.; Ye, Y.; Lu, X.; Wei, X.; Zeng, Y. Bererine induces peripheral lymphocytes immune regulations to realize its neuroprotective effects in the cerebral ischemia/reperfusion mice. Cell. Immunol. 2012, 276, 91-100. [CrossRef]

28. Kysenius, K.; Brunello, C.A.; Huttunen, H.J. Mitochondria and NMDA Receptor-Dependent Toxicity of Berberine Sensitizes Neurons to Glutamate and Rotenone Injury. PLoS ONE 2014, 9, e107129. [CrossRef]

29. Ayati, S.H.; Fazeli, B.; Momtazi-borojeni, A.A.; Cicero, A.F.G.; Pirro, M.; Sahebkar, A. Regulatory effects of berberine on microRNome in Cancer and other conditions. Crit. Rev. Oncol. Hematol. 2017, 116, 147-158. [CrossRef]

30. Imenshahidi, M.; Hosseinzadeh, H. Berberis Vulgaris and Berberine: An Update Review. Phytother. Res. 2016, 30, 1745-1764. [CrossRef]

31. Lee, B.; Yang, C.H.; Hahm, D.-H.; Choe, E.S.; Lee, H.-J.; Pyun, K.-H.; Shim, I. Inhibitory Effects of Coptidis rhizoma and Berberine on Cocaine-Induced Sensitization. eCAM 2009, 6, 85-90. [PubMed]

32. Wang, M.X.; Huo, L.M.; Yang, H.C.; Gao, Y.J. An experimental study on the photodynamic activity of berberine in vitro on cancer cells. J. Tradit. Chin. Med. Chung Tsa Chih Ying Wen Pan 1986, 6, 125-127.

33. Lin, C.-C.; Kao, S.-T.; Chen, G.-W.; Ho, H.-C.; Chung, J.-G. Apoptosis of Human Leukemia HL-60 Cells and Murine Leukemia WEHI-3 Cells Induced by Berberine through the Activation of Caspase-3. Anticancer Res. 2006, 26, 227-242. [PubMed]

34. Och, A.; Zalewski, D.; Komsta, Ł.; Kołodziej, P.; Kocki, J.; Bogucka-Kocka, A. Cytotoxic and Proapoptotic Activity of Sanguinarine, Berberine, and Extracts of Chelidonium majus L. and Berberis thunbergii DC. toward Hematopoietic Cancer Cell Lines. Toxins 2019, 11, 485. [CrossRef]

35. Jantová, S.; Čipák, L.; Čerňáková, M.; Košt'álová, D. Effect of berberine on proliferation, cell cycle and apoptosis in HeLa and L1210 cells. J. Pharm. Pharmacol. 2003, 55, 1143-1149. [CrossRef]

36. Kettmann, V.; Košt'álová, D.; Jantová, S.; Čerňáková, M.; DřímalInstitute of Experimental Pharmacology, Slovak Academy of Sciences, J. In vitro cytotoxicity of berberine against HeLa and L1210 cancer cell lines. Pharm. Int. J. Pharm. Sci. 2004, 59, 548-551.

37. Yu, F.-S.; Yang, J.-S.; Lin, H.-J.; Yu, C.-S.; Tan, T.-W.; Lin, Y.-T.; Lin, C.-C.; Lu, H.-F.; Chung, J.-G. Berberine Inhibits WEHI-3 Leukemia Cells In Vivo. In Vivo 2007, 21, 407-412.

38. Pazhang, Y.; Ahmadian, S.; Mahmoudian, M.; Shafiezadeh, M. Berberine-induced apoptosis via decreasing the survivin protein in K562 cell line. Med. Oncol. 2011, 28, 1577-1583. [CrossRef]

39. Lin, J.G.; Chung, J.G.; Wu, L.T.; Chen, G.W.; Chang, H.L.; Wang, T.F. Effects of Berberine on Arylamine N-Acetyltransferase Activity in Human Colon Tumor Cells. Am. J. Chin. Med. 1999, 27, 265-275. [CrossRef]

40. Tai, W.; Luo, H. The inhibit effect of berberine on human colon cell line cyclooxygenase-2. Zhonghua Nei Ke Za Zhi 2003, 42, 558-560.

41. Chung, J.G.; Wu, L.T.; Chu, C.B.; Jan, J.Y.; Ho, C.C.; Tsou, M.F.; Lu, H.F.; Chen, G.W.; Lin, J.G.; Wang, T.F. Effects of berberine on arylamine $\mathrm{N}$-acetyltransferase activity in human bladder tumour cells. Food Chem. Toxicol. 1999, 37, 319-326. [CrossRef]

42. Liu, Y.; Yu, H.; Zhang, C.; Cheng, Y.; Hu, L.; Meng, X.; Zhao, Y. Protective effects of berberine on radiation-induced lung injury via intercellular adhesion molecular-1 and transforming growth factor-beta-1 in patients with lung cancer. Eur. J. Cancer 2008, 44, 2425-2432. [CrossRef] [PubMed]

43. Noriyasu, M.; Murakami, K.; Yamaura, T.; Ikeda, T.; Saiki, I. Inhibitory effect of berberine on the mediastinal lymph node metastasis produced by orthotopic implantation of Lewis lung carcinoma. Cancer Lett. 2001, $165,35-42$. 
44. Wang, D.Y.; Yeh, C.C.; Lee, J.H.; Hung, C.F.; Chung, J.G. Berberine Inhibited Arylamine N-Acetyltransferase Activity and Gene Expression and DNA Adduct Formation in Human Malignant Astrocytoma (G9T/VGH) and Brain Glioblastoma Multiforms (GBM 8401) Cells. Neurochem. Res. 2002, 27, 883-889. [CrossRef] [PubMed]

45. Letašiová, S.; Jantová, S.; Čipák, L.; Múčková, M. Berberine-Antiproliferative activity in vitro and induction of apoptosis/necrosis of the U937 and B16 cells. Cancer Lett. 2006, 239, 254-262. [CrossRef]

46. Palmieri, A.; Scapoli, L.; Iapichino, A.; Mercolini, L.; Mandrone, M.; Poli, F.; Giannì, A.B.; Baserga, C.; Martinelli, M. Berberine and Tinospora cordifolia exert a potential anticancer effect on colon cancer cells by acting on specific pathways. Int. J. Immunopathol. Pharmacol. 2019, 33. [CrossRef]

47. Liu, D.; Meng, X.; Wu, D.; Qiu, Z.; Luo, H. A Natural Isoquinoline Alkaloid With Antitumor Activity: Studies of the Biological Activities of Berberine. Front. Pharmacol. 2019, 10. [CrossRef]

48. Yang, M.; Yang, Y.; Cui, H.; Guan, Z.; Yang, Y.; Zhang, H.; Chen, X.; Zhu, H.; Yang, X.; Cai, J.; et al. The Natural Compound Gambogic Acid Radiosensitizes Nasopharyngeal Carcinoma Cells under Hypoxic Conditions. Tumori J. 2016, 102, 135-143. [CrossRef]

49. Li, L.; Wang, X.; Sharvan, R.; Gao, J.; Qu, S. Berberine could inhibit thyroid carcinoma cells by inducing mitochondrial apoptosis, G0/G1 cell cycle arrest and suppressing migration via PI3K-AKT and MAPK signaling pathways. Biomed. Pharmacother. 2017, 95, 1225-1231. [CrossRef]

50. Yan, K.; Zhang, C.; Feng, J.; Hou, L.; Yan, L.; Zhou, Z.; Liu, Z.; Liu, C.; Fan, Y.; Zheng, B.; et al. Induction of G1 cell cycle arrest and apoptosis by berberine in bladder cancer cells. Eur. J. Pharmacol. 2011, 661, 1-7. [CrossRef]

51. Gong, C.; Hu, X.; Xu, Y.; Yang, J.; Zong, L.; Wang, C.; Zhu, J.; Li, Z.; Lu, D. Berberine inhibits proliferation and migration of colorectal cancer cells by downregulation of GRP78. Anticancer. Drugs 2020, 31, 141-149. [CrossRef] [PubMed]

52. Dai, W.; Mu, L.; Cui, Y.; Li, Y.; Chen, P.; Xie, H.; Wang, X. Long non-coding RNA CASC2 enhances berberine-induced cytotoxicity in colorectal cancer cells by silencing BCL2. Mol. Med. Rep. 2019, 20, 995-1006. [CrossRef] [PubMed]

53. Liu, Y.; Hua, W.; Li, Y.; Xian, X.; Zhao, Z.; Liu, C.; Zou, J.; Li, J.; Fang, X.; Zhu, Y. Berberine suppresses colon cancer cell proliferation by inhibiting the SCAP/SREBP-1 signaling pathway-mediated lipogenesis. Biochem. Pharmacol. 2020, 174, 113776. [CrossRef] [PubMed]

54. Farooqi, A.A.; Qureshi, M.Z.; Khalid, S.; Attar, R.; Martinelli, C.; Sabitaliyevich, U.Y.; Nurmurzayevich, S.B.; Taverna, S.; Poltronieri, P.; Xu, B. Regulation of Cell Signaling Pathways by Berberine in Different Cancers: Searching for Missing Pieces of an Incomplete Jig-Saw Puzzle for an Effective Cancer Therapy. Cancers 2019, 11, 478. [CrossRef]

55. Hu, X.; Wu, X.; Huang, Y.; Tong, Q.; Takeda, S.; Qing, Y. Berberine induces double-strand DNA breaks in Rev3 deficient cells. Mol. Med. Rep. 2014, 9, 1883-1888. [CrossRef]

56. Chidambara Murthy, K.N.; Jayaprakasha, G.K.; Patil, B.S. The natural alkaloid berberine targets multiple pathways to induce cell death in cultured human colon cancer cells. Eur. J. Pharmacol. 2012, 688, 14-21. [CrossRef]

57. Kalaiarasi, A.; Anusha, C.; Sankar, R.; Rajasekaran, S.; John Marshal, J.; Muthusamy, K.; Ravikumar, V. Plant Isoquinoline Alkaloid Berberine Exhibits Chromatin Remodeling by Modulation of Histone Deacetylase To Induce Growth Arrest and Apoptosis in the A549 Cell Line. J. Agric. Food Chem. 2016, 64, 9542-9550. [CrossRef]

58. Su, Y.-H.; Tang, W.-C.; Cheng, Y.-W.; Sia, P.; Huang, C.-C.; Lee, Y.-C.; Jiang, H.-Y.; Wu, M.-H.; Lai, I.-L.; Lee, J.-W.; et al. Targeting of multiple oncogenic signaling pathways by Hsp90 inhibitor alone or in combination with berberine for treatment of colorectal cancer. Biochim. Biophys. Acta BBA Mol. Cell Res. 2015, 1853, 2261-2272. [CrossRef]

59. Sanna, L.; Marchesi, I.; Melone, M.A.B.; Bagella, L. The role of enhancer of zeste homolog 2: From viral epigenetics to the carcinogenesis of hepatocellular carcinoma. J. Cell. Physiol. 2018, 233, 6508-6517. [CrossRef]

60. Refaat, A.; Abdelhamed, S.; Yagita, H.; Inoue, H.; Yokoyama, S.; Hayakawa, Y.; Saiki, I. Berberine enhances tumor necrosis factor-related apoptosis-inducing ligand-mediated apoptosis in breast cancer. Oncol. Lett. 2013, 6, 840-844. [CrossRef] 
61. Hsu, W.-H.; Hsieh, Y.-S.; Kuo, H.-C.; Teng, C.-Y.; Huang, H.-I.; Wang, C.-J.; Yang, S.-F.; Liou, Y.-S.; Kuo, W.-H. Berberine induces apoptosis in SW620 human colonic carcinoma cells through generation of reactive oxygen species and activation of JNK/p38 MAPK and FasL. Arch. Toxicol. 2007, 81, 719-728. [CrossRef] [PubMed]

62. Lu, B.; Hu, M.; Liu, K.; Peng, J. Cytotoxicity of berberine on human cervical carcinoma HeLa cells through mitochondria, death receptor and MAPK pathways, and in-silico drug-target prediction. Toxicol. Vitr. 2010, 24, 1482-1490. [CrossRef] [PubMed]

63. Zarubin, T.; Han, J. Activation and signaling of the p38 MAP kinase pathway. Cell Res. 2005, 15, 11-18. [CrossRef] [PubMed]

64. Renault, V.M.; Thekkat, P.U.; Hoang, K.L.; White, J.L.; Brady, C.A.; Kenzelmann Broz, D.; Venturelli, O.S.; Johnson, T.M.; Oskoui, P.R.; Xuan, Z.; et al. The pro-longevity gene FoxO3 is a direct target of the p53 tumor suppressor. Oncogene 2011, 30, 3207-3221. [CrossRef] [PubMed]

65. Macleod, K.F.; Sherry, N.; Hannon, G.; Beach, D.; Tokino, T.; Kinzler, K.; Vogelstein, B.; Jacks, T. p53-dependent and independent expression of p21 during cell growth, differentiation, and DNA damage. Genes Dev. 1995, 9, 935-944. [CrossRef]

66. Hauck, L.; Harms, C.; Grothe, D.; An, J.; Gertz, K.; Kronenberg, G.; Dietz, R.; Endres, M.; von Harsdorf, R. Critical Role for FoxO3a-Dependent Regulation of p21CIP1/WAF1 in Response to Statin Signaling in Cardiac Myocytes. Circ. Res. 2007, 100, 50-60. [CrossRef]

67. Brunet, A.; Bonni, A.; Zigmond, M.J.; Lin, M.Z.; Juo, P.; Hu, L.S.; Anderson, M.J.; Arden, K.C.; Blenis, J.; Greenberg, M.E. Akt Promotes Cell Survival by Phosphorylating and Inhibiting a Forkhead Transcription Factor. Cell 1999, 96, 857-868. [CrossRef]

68. Schmidt, M.; de Mattos, S.F.; van der Horst, A.; Klompmaker, R.; Kops, G.J.P.L.; Lam, E.W.-F.; Burgering, B.M.T.; Medema, R.H. Cell Cycle Inhibition by FoxO Forkhead Transcription Factors Involves Downregulation of Cyclin D. Mol. Cell. Biol. 2002, 22, 7842-7852. [CrossRef]

69. Yang, J.-Y.; Zong, C.S.; Xia, W.; Yamaguchi, H.; Ding, Q.; Xie, X.; Lang, J.-Y.; Lai, C.-C.; Chang, C.-J.; Huang, W.-C.; et al. ERK promotes tumorigenesis by inhibiting FOXO3a via MDM2-mediated degradation. Nat. Cell Biol. 2008, 10, 138-148. [CrossRef]

70. Gazon, H.; Barbeau, B.; Mesnard, J.-M.; Peloponese, J.-M.J. Hijacking of the AP-1 Signaling Pathway during Development of ATL. Front. Microbiol. 2018, 8. [CrossRef]

71. Abate, C.; Curran, T. Encounters with Fos and Jun on the road to AP-1. Semin. Cancer Biol. 1990, 1, 19-26. [PubMed]

72. Neyns, B.; Vermeij, J.K.; Bourgain, C.; Vandamme, B.; Amfo, K.; Lissens, W.; DeSutter, P.; Hooghe-Peters, E.; DeGrève, J. Expression of the jun family of genes in human ovarian cancer and normal ovarian surface epithelium. Oncogene 1996, 12, 1247-1257. [PubMed]

73. Langer, S.; Singer, C.F.; Hudelist, G.; Dampier, B.; Kaserer, K.; Vinatzer, U.; Pehamberger, H.; Zielinski, C.; Kubista, E.; Schreibner, M. Jun and Fos family protein expression in human breast cancer: Correlation of protein expression and clinicopathological parameters. Eur. J. Gynaecol. Oncol. 2006, 27, 345-352.

74. Kharman-Biz, A.; Gao, H.; Ghiasvand, R.; Zhao, C.; Zendehdel, K.; Dahlman-Wright, K. Expression of activator protein-1 (AP-1) family members in breast cancer. BMC Cancer 2013, 13, 441. [CrossRef] [PubMed]

75. Drakos, E.; Leventaki, V.; Schlette, E.J.; Jones, D.; Lin, P.; Jeffrey Medeiros, L.; Rassidakis, G.Z. c-Jun Expression and Activation are Restricted to CD30+ Lymphoproliferative Disorders. Am. J. Surg. Pathol. 2007, 31, 447-453. [CrossRef]

76. Mao, X.; Orchard, G.; Russell-Jones, R.; Whittaker, S. Abnormal activator protein 1 transcription factor expression in CD30-positive cutaneous large-cell lymphomas. Br. J. Dermatol. 2007, 157, 914-921. [CrossRef]

77. Tulchinsky, E. Fos family members: Regulation, structure and role in oncogenic transformation. Histol. Histopathol. 2000. [CrossRef]

78. Fukuda, K.; Hibiya, Y.; Mutoh, M.; Koshiji, M.; Akao, S.; Fujiwara, H. Inhibition by berberine of cyclooxygenase-2 transcriptional activity in human colon cancer cells. J. Ethnopharmacol. 1999, 66, 227-233. [CrossRef]

79. Björklund, M.; Koivunen, E. Gelatinase-mediated migration and invasion of cancer cells. Biochim. Biophys. Acta 2005, 1755, 37-69. [CrossRef]

80. Mook, O.R.F.; Frederiks, W.M.; Van Noorden, C.J.F. The role of gelatinases in colorectal cancer progression and metastasis. Biochim. Biophys. Acta 2004, 1705, 69-89. [CrossRef] [PubMed] 
81. Montgomery, A.M.; Reisfeld, R.A.; Cheresh, D.A. Integrin alpha v beta 3 rescues melanoma cells from apoptosis in three-dimensional dermal collagen. Proc. Natl. Acad. Sci. USA 1994, 91, 8856-8860. [CrossRef] [PubMed]

82. Hamsa, T.P.; Kuttan, G. Antiangiogenic activity of berberine is mediated through the downregulation of hypoxia-inducible factor-1, VEGF, and proinflammatory mediators. Drug Chem. Toxicol. 2012, 35, 57-70. [CrossRef] [PubMed]

83. Liu, X.; Ji, Q.; Ye, N.; Sui, H.; Zhou, L.; Zhu, H.; Fan, Z.; Cai, J.; Li, Q. Berberine Inhibits Invasion and Metastasis of Colorectal Cancer Cells via COX-2/PGE2 Mediated JAK2/STAT3 Signaling Pathway. PLoS ONE 2015, 10, e0123478. [CrossRef] [PubMed]

84. Huang, C.; Zhang, Y.; Gong, Z.; Sheng, X.; Li, Z.; Zhang, W.; Qin, Y. Berberine inhibits 3T3-L1 adipocyte differentiation through the PPARgamma pathway. Biochem. Biophys. Res. Commun. 2006, 348, 571-578. [CrossRef]

85. Rojiani, M.V.; Alidina, J.; Esposito, N.; Rojiani, A.M. Expression of MMP-2 correlates with increased angiogenesis in CNS metastasis of lung carcinoma. Int. J. Clin. Exp. Pathol. 2010, 3, 775-781.

86. Hwang, J.-M.; Kuo, H.-C.; Tseng, T.-H.; Liu, J.-Y.; Chu, C.-Y. Berberine induces apoptosis through a mitochondria/caspases pathway in human hepatoma cells. Arch. Toxicol. 2006, 80, 62-73. [CrossRef]

87. Yount, G.; Qian, Y.; Moore, D.; Basila, D.; West, J.; Aldape, K.; Arvold, N.; Shalev, N.; Haas-Kogan, D. Berberine sensitizes human glioma cells, but not normal glial cells, to ionizing radiation in vitro. J. Exp. Ther. Oncol. 2004, 4, 137-143.

88. Qi, H.; Xin, L.; Xu, X.; Ji, X.; Fan, L. Epithelial-to-mesenchymal transition markers to predict response of Berberine in suppressing lung cancer invasion and metastasis. J. Transl. Med. 2014, 12, 22. [CrossRef]

89. Gialeli, C.; Theocharis, A.D.; Karamanos, N.K. Roles of matrix metalloproteinases in cancer progression and their pharmacological targeting. FEBS J. 2011, 278, 16-27. [CrossRef]

90. McCawley, L.J.; Matrisian, L.M. Matrix metalloproteinases: Multifunctional contributors to tumor progression. Mol. Med. Today 2000, 6, 149-156. [CrossRef]

91. Detry, B.; Erpicum, C.; Paupert, J.; Blacher, S.; Maillard, C.; Bruyère, F.; Pendeville, H.; Remacle, T.; Lambert, V.; Balsat, C.; et al. Matrix metalloproteinase-2 governs lymphatic vessel formation as an interstitial collagenase. Blood 2012, 119, 5048-5056. [CrossRef] [PubMed]

92. Massagué, J. TGFbeta in Cancer. Cell 2008, 134, 215-230. [CrossRef] [PubMed]

93. Li, L.; Peng, Z.; Hu, Q.; Xu, L.; Zou, X.; Yu, Y.; Huang, D.; Yi, P. Berberine Suppressed Tumor Growth through Regulating Fatty Acid Metabolism and Triggering Cell Apoptosis via Targeting FABPs. Evid. Based Complement. Alternat. Med. 2020, 2020, 16. [CrossRef] [PubMed]

94. Sun, Y.; Wang, W.; Tong, Y. Berberine Inhibits Proliferative Ability of Breast Cancer Cells by Reducing Metadherin. Med. Sci. Monit. Int. Med. J. Exp. Clin. Res. 2019, 25, 9058-9066. [CrossRef] [PubMed]

95. Zhao, L.; Zhang, C. Berberine Inhibits MDA-MB-231 Cells by Attenuating Their Inflammatory Responses. BioMed Res. Int. 2020, 2020, 3617514. [CrossRef]

96. Lopes, T.Z.; de Moraes, F.R.; Tedesco, A.C.; Arni, R.K.; Rahal, P.; Calmon, M.F. Berberine associated photodynamic therapy promotes autophagy and apoptosis via ROS generation in renal carcinoma cells. Biomed. Pharmacother. Biomed. Pharmacother. 2020, 123, 109794. [CrossRef]

97. You, X.; Cao, X.; Lin, Y. Berberine enhances the radiosensitivity of hepatoma cells by Nrf2 pathway. Front. Biosci. Landmark Ed. 2019, 24, 1190-1202.

98. Ashrafizadeh, M.; Fekri, H.S.; Ahmadi, Z.; Farkhondeh, T.; Samarghandian, S. Therapeutic and biological activities of berberine: The involvement of Nrf2 signaling pathway. J. Cell. Biochem. 2020, 121, 1575-1585. [CrossRef]

99. Gao, X.; Wang, J.; Li, M.; Wang, J.; Lv, J.; Zhang, L.; Sun, C.; Ji, J.; Yang, W.; Zhao, Z.; et al. Berberine attenuates XRCC1-mediated base excision repair and sensitizes breast cancer cells to the chemotherapeutic drugs. J. Cell. Mol. Med. 2019, 23, 6797-6804. [CrossRef]

100. Liu, L.; Fan, J.; Ai, G.; Liu, J.; Luo, N.; Li, C.; Cheng, Z. Berberine in combination with cisplatin induces necroptosis and apoptosis in ovarian cancer cells. Biol. Res. 2019, 52. [CrossRef]

101. Zheng, F.; Li, J.; Ma, C.; Tang, X.; Tang, Q.; Wu, J.; Chai, X.; Xie, J.; Yang, X.-B.; Hann, S.S. Novel regulation of miR-34a-5p and HOTAIR by the combination of berberine and gefitinib leading to inhibition of EMT in human lung cancer. J. Cell. Mol. Med. 2020, 24, 5578-5592. [CrossRef] [PubMed] 
102. Zhang, F.; Jia, Y.; Zheng, X.; Shao, D.; Zhao, Y.; Wang, Z.; Dawulieti, J.; Liu, W.; Sun, M.; Sun, W.; et al. Janus nanocarrier-based co-delivery of doxorubicin and berberine weakens chemotherapy-exacerbated hepatocellular carcinoma recurrence. Acta Biomater. 2019, 100, 352-364. [CrossRef] [PubMed]

103. Liu, J.; Zhu, Z.; Liu, Y.; Wei, L.; Li, B.; Mao, F.; Zhang, J.; Wang, Y.; Liu, Y. MDM2 inhibition-mediated autophagy contributes to the pro-apoptotic effect of berberine in p53-null leukemic cells. Life Sci. 2020, 242, 117228. [CrossRef] [PubMed]

104. Wang, Y.; Liu, Y.; Du, X.; Ma, H.; Yao, J. Berberine Reverses Doxorubicin Resistance by Inhibiting Autophagy Through the PTEN/Akt/mTOR Signaling Pathway in Breast Cancer. OncoTargets Ther. 2020, 13, 1909-1919. [CrossRef]

105. Khan, I.; Joshi, G.; Nakhate, K.T.; Kumar, R.; Gupta, U. Nano-Co-Delivery of Berberine and Anticancer Drug Using PLGA Nanoparticles: Exploration of Better Anticancer Activity and In Vivo Kinetics. Pharm. Res. 2019, 36, 149. [CrossRef]

106. Maiti, P.; Plemmons, A.; Dunbar, G.L. Combination treatment of berberine and solid lipid curcumin particles increased cell death and inhibited PI3K/Akt/mTOR pathway of human cultured glioblastoma cells more effectively than did individual treatments. PLoS ONE 2019, 14, e0225660. [CrossRef]

107. Qin, Q.-P.; Wang, Z.-F.; Huang, X.-L.; Tan, M.-X.; Luo, Z.-H.; Wang, S.-L.; Zou, B.-Q.; Liang, H. Two telomerase-targeting $\mathrm{Pt}(\mathrm{II})$ complexes of jatrorrhizine and berberine derivatives induce apoptosis in human bladder tumor cells. Dalton Trans. 2019, 48, 15247-15254. [CrossRef]

108. Li, X.-D.; Wang, Z.; Wang, X.-R.; Shao, D.; Zhang, X.; Li, L.; Ge, M.-F.; Chang, Z.-M.; Dong, W.-F. Berberine-loaded Janus gold mesoporous silica nanocarriers for chemo/radio/photothermal therapy of liver cancer and radiation-induced injury inhibition. Int. J. Nanomed. 2019, 14, 3967-3982. [CrossRef]

109. Suganthi, S.; Sivaraj, R.; Enoch, I.V.M.V. Molecular encapsulation of berberine by a modified $\beta$-cyclodextrin and binding of host: Guest complex to G-quadruplex DNA. Nucleosides Nucleotides Nucleic Acids 2019, 38, 858-873. [CrossRef]

110. De Francesco, E.M.; Ózsvári, B.; Sotgia, F.; Lisanti, M.P. Dodecyl-TPP Targets Mitochondria and Potently Eradicates Cancer Stem Cells (CSCs): Synergy With FDA-Approved Drugs and Natural Compounds (Vitamin C and Berberine). Front. Oncol. 2019, 9. [CrossRef]

111. Xu, L.; Zhang, Y.; Xue, X.; Liu, J.; Li, Z.-S.; Yang, G.-Y.; Song, Y.; Pan, Y.; Ma, Y.; Hu, S.; et al. A Phase I Trial of Berberine in Chinese with Ulcerative Colitis. Cancer Prev. Res. 2020, 13, 117-126. [CrossRef]

112. Hallajzadeh, J.; Maleki Dana, P.; Mobini, M.; Asemi, Z.; Mansournia, M.A.; Sharifi, M.; Yousefi, B. Targeting of oncogenic signaling pathways by berberine for treatment of colorectal cancer. Med. Oncol. 2020, 37, 49. [CrossRef]

113. Wang, B.; Deng, A.-J.; Li, Z.-H.; Wang, N.; Qin, H.-L. Syntheses and Structure-Activity Relationships in Growth Inhibition Activity against Human Cancer Cell Lines of 12 Substituted Berberine Derivatives. Molecules 2020, 25, 1871. [CrossRef]

114. Zhang, C.; Sheng, J.; Li, G.; Zhao, L.; Wang, Y.; Yang, W.; Yao, X.; Sun, L.; Zhang, Z.; Cui, R. Effects of Berberine and Its Derivatives on Cancer: A Systems Pharmacology Review. Front. Pharmacol. 2020, 10. [CrossRef]

115. Jin, H.; Ko, Y.S.; Park, S.W.; Chang, K.C.; Kim, H.J. 13-Ethylberberine Induces Apoptosis through the Mitochondria-Related Apoptotic Pathway in Radiotherapy-Resistant Breast Cancer Cells. Molecules 2019, 24, 2448. [CrossRef]

116. Milata, V.; Svedova, A.; Barbierikova, Z.; Holubkova, E.; Cipakova, I.; Cholujova, D.; Jakubikova, J.; Panik, M.; Jantova, S.; Brezova, V.; et al. Synthesis and Anticancer Activity of Novel 9-O-Substituted Berberine Derivatives. Int. J. Mol. Sci. 2019, 20, 2169. [CrossRef]

117. Wang, Z.-C.; Wang, J.; Chen, H.; Tang, J.; Bian, A.-W.; Liu, T.; Yu, L.-F.; Yi, Z.; Yang, F. Synthesis and anticancer activity of novel 9,13-disubstituted berberine derivatives. Bioorg. Med. Chem. Lett. 2020, 30, 126821. [CrossRef]

118. Lin, H.-J.; Ho, J.-H.; Tsai, L.-C.; Yang, F.-Y.; Yang, L.-L.; Kuo, C.-D.; Chen, L.-G.; Liu, Y.-W.; Wu, J.-Y. Synthesis and In Vitro Photocytotoxicity of 9-/13-Lipophilic Substituted Berberine Derivatives as Potential Anticancer Agents. Molecules 2020, 25, 677. [CrossRef]

119. Li, G.; Ren, Y.; Zhang, X.; Zhao, S.; Wang, Y.; Wu, J.; Peng, S.; Zhao, M. 13-[CH2CO-Cys-(Bzl)-OBzl]-Berberine: Exploring The Correlation Of Anti-Tumor Efficacy With ROS And Apoptosis Protein. OncoTargets Ther. 2019, 12, 10651-10662. [CrossRef] 
120. Liu, Y.; Zhu, K.; Cao, L.; Xie, Z.; Gu, M.; Lü, W.; Li, J.; Nan, F. Berberine derivatives with a long alkyl chain branched by hydroxyl group and methoxycarbonyl group at 9-position show improved anti-proliferation activity and membrane permeability in A549 cells. Acta Pharmacol. Sin. 2020, 41, 813-824. [CrossRef]

121. Du, P.; Yan, J.; Long, S.; Xiong, H.; Wen, N.; Cai, S.; Wang, Y.; Peng, D.; Liu, Z.; Liu, Y. Tumor microenvironment and NIR laser dual-responsive release of berberine 9-O-pyrazole alkyl derivative loaded in graphene oxide nanosheets for chemo-photothermal synergetic cancer therapy. J. Mater. Chem. B 2020, 8, 4046-4055. [CrossRef] [PubMed]

122. Leyva-Peralta, M.A.; Robles-Zepeda, R.E.; Razo-Hernández, R.S.; Berber, L.P.Á.; Lara, K.O.; Ruiz-Bustos, E.; Gálvez-Ruíz, J.C. Berberine as Source of Antiproliferative Hybrid Compounds: In Vitro Antiproliferative Activity and Quantitative Structure-activity Relationship. Anticancer Agents Med. Chem. 2019, 19, 1820-1834. [CrossRef] [PubMed]

123. Home-ClinicalTrials.gov. Available online: https://clinicaltrials.gov/ (accessed on 6 September 2020).

124. Wei, X.; Zhu, L.; Wang, C. Efficacy and Safety of Berberine in Patients with Type 2 Diabetes Mellitus: A Meta-Analysis. Chin. Herb. Med. 2015, 7, 344-353. [CrossRef]

125. Derosa, G.; D'Angelo, A.; Vanelli, A.; Maffioli, P. An Evaluation of a Nutraceutical with Berberine, Curcumin, Inositol, Banaba and Chromium Picolinate in Patients with Fasting Dysglycemia. Diabetes Metab. Syndr. Obes. Targets Ther. 2020, 13, 653-661. [CrossRef]

126. Pérez-Rubio, K.G.; González-Ortiz, M.; Martínez-Abundis, E.; Robles-Cervantes, J.A.; Espinel-Bermúdez, M.C. Effect of Berberine Administration on Metabolic Syndrome, Insulin Sensitivity, and Insulin Secretion. Metab. Syndr. Relat. Disord. 2013, 11, 366-369. [CrossRef]

127. Chen, Y.-X.; Gao, Q.-Y.; Zou, T.-H.; Wang, B.-M.; Liu, S.-D.; Sheng, J.-Q.; Ren, J.-L.; Zou, X.-P.; Liu, Z.-J.; Song, Y.-Y.; et al. Berberine versus placebo for the prevention of recurrence of colorectal adenoma: A multicentre, double-blinded, randomised controlled study. Lancet Gastroenterol. Hepatol. 2020, 5, 267-275. [CrossRef]

128. Gonnelli, S.; Caffarelli, C.; Stolakis, K.; Cuda, C.; Giordano, N.; Nuti, R. Efficacy and Tolerability of a Nutraceutical Combination (Red Yeast Rice, Policosanols, and Berberine) in Patients with Low-Moderate Risk Hypercholesterolemia: A Double-Blind, Placebo-Controlled Study. Curr. Ther. Res. 2015, 77, 1-6. [CrossRef]

129. Yan, H.-M.; Xia, M.-F.; Wang, Y.; Chang, X.-X.; Yao, X.-Z.; Rao, S.-X.; Zeng, M.-S.; Tu, Y.-F.; Feng, R.; Jia, W.-P.; et al. Efficacy of Berberine in Patients with Non-Alcoholic Fatty Liver Disease. PLoS ONE 2015, 10, e0134172. [CrossRef]

130. Cereda, E.; Cappello, S.; Caraccia, M.; Turri, A.; Masi, S.; Nappi, R.; Caccialanza, R. SUN-PO004: Nutraceutical Intervention with Berberine, Chlorogenic Acid and Tocotrienols for Menopause-Associated Dyslipidemia: A Pilot, Single-ARM Trial. Clin. Nutr. 2019, 38, S60. [CrossRef]

131. Zhang, D.; Ke, L.; Ni, Z.; Chen, Y.; Zhang, L.-H.; Zhu, S.-H.; Li, C.-J.; Shang, L.; Liang, J.; Shi, Y.-Q. Berberine containing quadruple therapy for initial Helicobacter pylori eradication. Medicine 2017, 96. [CrossRef]

132. Mirhadi, E.; Rezaee, M.; Malaekeh-Nikouei, B. Nano strategies for berberine delivery, a natural alkaloid of Berberis. Biomed. Pharmacother. 2018, 104, 465-473. [CrossRef] [PubMed]

Publisher's Note: MDPI stays neutral with regard to jurisdictional claims in published maps and institutional affiliations.

(C) 2020 by the authors. Licensee MDPI, Basel, Switzerland. This article is an open access article distributed under the terms and conditions of the Creative Commons Attribution (CC BY) license (http://creativecommons.org/licenses/by/4.0/). 